\title{
Depth-to-basement for the East European Craton and Teisseyre- Tornquist Zone in Poland based on potential field data
}

\author{
Mateusz Mikołajczak ${ }^{1}$ (D) . Stanisław Mazur ${ }^{1}$ (D) Łukasz Gągała $^{2}$
}

Received: 7 December 2017 / Accepted: 28 November 2018 / Published online: 19 December 2018

(c) The Author(s) 2018

\begin{abstract}
Results of a depth-to-basement study are presented for the East European Craton and the Teisseyre-Tornquist Zone (TTZ) in Poland. The terrestrial gravity data are inverted for the top of the Paleoproterozoic basement and, independently, for the top of the Ediacaran using seismic horizons from the PolandSPANTM seismic survey and well tops as input depth measurements. The depth to the Ediacaran modelling was additionally extended to cover the Łysogóry Block and northern Małopolska Block. The results are visualised as isobath maps for the top of the Paleoproterozoic basement and top of the Ediacaran and an isopach map for the Ediacaran, supplemented with qualitative structural interpretation based on gravity and magnetic data. The results of modelling show a smooth crystalline basement slope within the TTZ with the top of the Paleoproterozoic basement uniformly descending south-westwards by $10-14 \mathrm{~km}$. The thickness of the Ediacaran in SE Poland increases in the same direction to more than $10 \mathrm{~km}$ within the TTZ. Such a crustal architecture, in combination with the earlier documented Moho elevation of 4-6 km, reveals significant thinning of the Paleoproterozoic crust within the TTZ to form a crustal necking zone due to the Ediacaran rifting. A smooth geometry of the top of basement along with the lack of basement-rooted faults suggests a ductile mode of crustal thinning during rifting of Rodinia. Moreover, the development of the NW-SE-oriented rift, a precursor of the Tornquist Ocean, was associated with rifting in a NE-SW direction parallel to the Orsha-Volyn Rift.
\end{abstract}

Keywords Gravity inversion $\cdot$ Crystalline basement $\cdot$ Ediacaran $\cdot$ Rodinia break-up $\cdot$ Tectonics $\cdot$ PolandSPAN survey

\section{Introduction}

The south-western slope of the East European Craton (EEC) and the Teisseyre-Tornquist Zone (TTZ) have a key significance for understanding the transition from old Precambrian Europe in the east to younger Palaeozoic Europe in the west (Fig. 1; e.g., Pharaoh 1999; Winchester et al.

Electronic supplementary material The online version of this article (https://doi.org/10.1007/s00531-018-1668-9) contains supplementary material, which is available to authorized users.

Mateusz Mikołajczak

ndmikola@cyf-kr.edu.pl

Stanisław Mazur

ndmazur@cyf-kr.edu.pl

Łukasz Gagała

lukasz.gagala@hotmail.com

1 Institute of Geological Sciences, Polish Academy of Sciences, Senacka 1, 31-002 Kraków, Poland

2 Hellenic Petroleum, Maroussi, Greece
2002; Guterch et al. 2010). The area is entirely concealed beneath sediments ranging in age from Ediacaran to recent with the top of the Paleoproterozoic basement gradually sloping south-westwards to a depth exceeding the reach of wells. Therefore, geophysical methods are needed to understand the junction between the two domains. In particular, depth-to-basement studies provide important constraints on crustal architecture and geological evolution of the transition between the old Precambrian craton and younger Palaeozoic Platform (Mazur et al. 2015, 2016a; Krzywiec et al. 2017a). Potential field modelling complements seismic studies (e.g., Grad and Polkowski 2016; Grad et al. 2016) and aids in providing a continuous coverage of depth-to-top-basement across the area of interest and filling the gaps between individual seismic surveys.

A number of studies have deployed gravity modelling for the area located at the junction between the EEC and the Palaeozoic Platform of Western Europe (Bayer et al. 2002; Yegorova et al. 2007; Maystrenko and Scheck-Wenderoth 2013) providing general insight into the crustal configuration. However, the availability of higher resolution gravity 


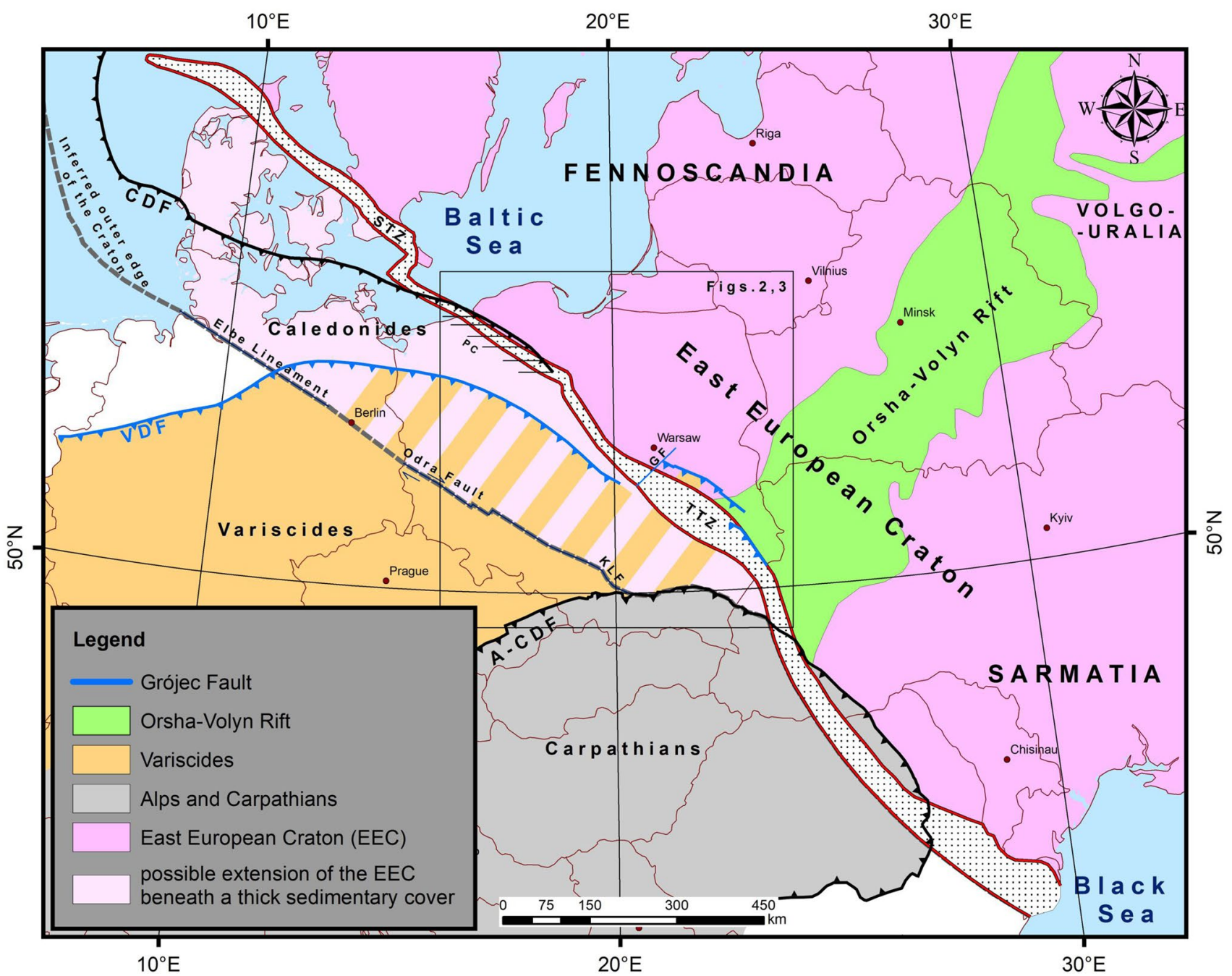

Fig. 1 Simplified tectonic map of Central Europe showing the extent of the East European Craton, the main structural elements and the position of the Orsha-Volyn Rift. Base map modified from several sources including Bogdanova et al. (2008). Mixed orange and pale pink stripes mean Baltica margin covered by the Variscan belt and

and magnetic data as well as acquisition of the first regional high-resolution seismic reflection surveys (Malinowski et al. 2013; Krzywiec et al. 2014) inspired a detailed depth-totop-basement study. Following the recent concepts concerning the nature of the TTZ (Mazur et al. 2015, 2016a, b; Smit et al. 2016), we used the depth-to-top-basement study, combined with the Moho map based on seismic refraction experiments (Majdański 2012; Grad and Polkowski 2016), to better understand the crustal architecture of the TTZ and the extent of the EEC margin.

The gravity data were inverted for the top of the Paleoproterozoic basement and separately for the top of the Ediacaran using reflection seismic horizons and well tops for depth calibration. The area of the top of the Paleoproterozoic basement modelling (Fig. 2) was equivalent to the extent of its foreland basin. A-CDF Alpine-Carpathian Deformation Front, $C D F$ Caledonian Deformation Front, GF Grójec Fault, KLF KrakówLubliniec Fault, $P C$ Pomeranian Caledonides (horizontal hatching), STZ Sorgenfrei-Tornquist Zone, TTZ Teisseyre-Tornquist Zone, VDF Variscan Deformation Front

the PolandSPANTM seismic survey (Krzywiec et al. 2014). The depth to the Ediacaran study was additionally extended to cover the Łysogóry Block and the northern part of the Małopolska Block (Figs. 2, 3). This was achieved using: (a) a large number of wells penetrating the Ediacaran in the NE part of the Małopolska Block; (b) the NE section of the POLCRUST-01 seismic profile (Malinowski et al. 2013); (c) two composite geological cross-sections that were built for the Łysogóry Block (Mazur et al. 2018; Gagała et al. 2018; Fig. 2). We used the top of the Paleoproterozoic basement and top of the Ediacaran horizons calculated in this study to advocate vast thinning of the Precambrian crust within the TTZ due to the Rodinia break-up and continuation of the attenuated rifted margin, originally belonging to Baltica, southwest of the TTZ. 


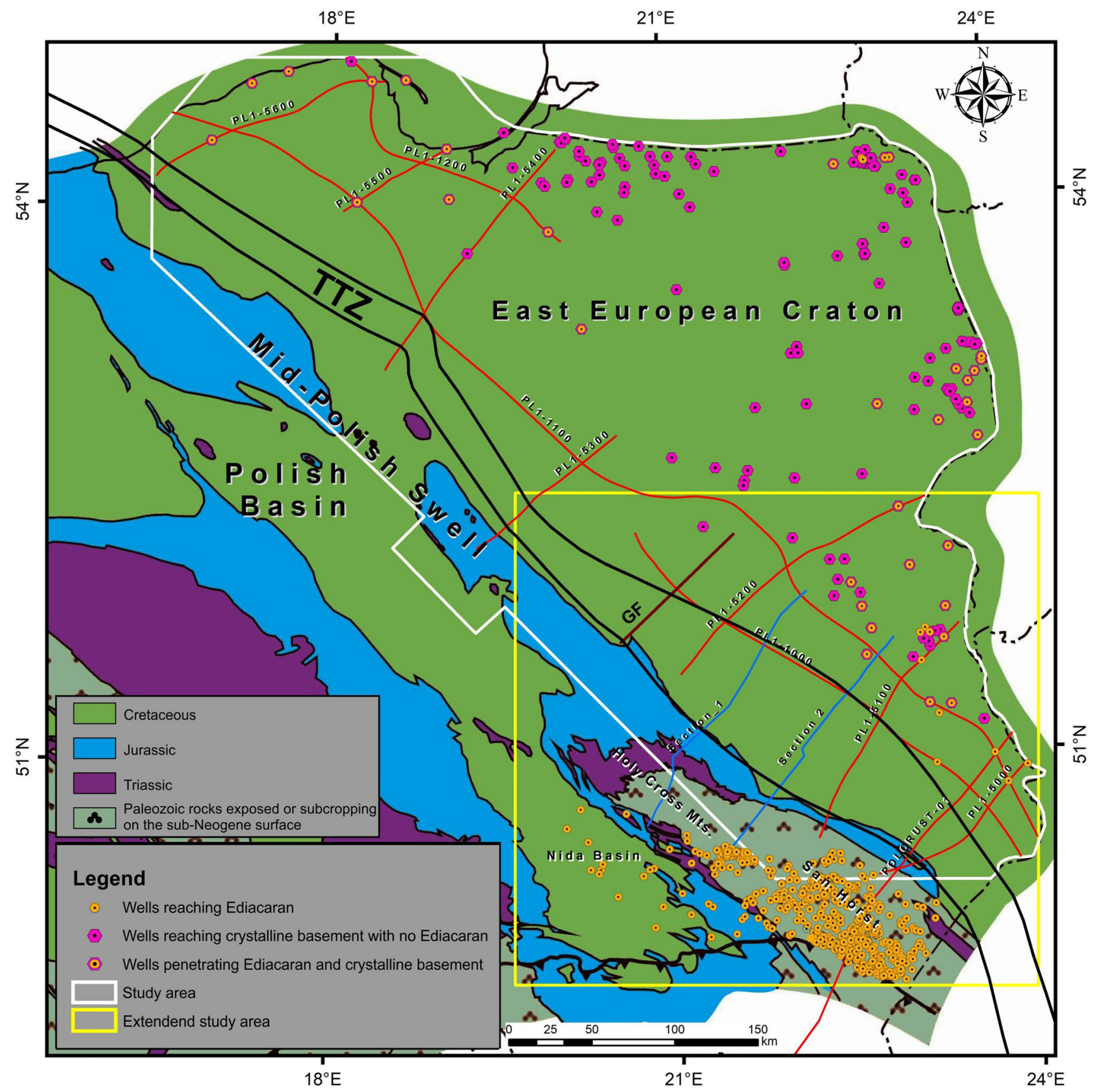

Fig. 2 Location of the study area on the background of the geological map of Poland without Cenozoic sediments (modified after Dadlez et al. 2000). The map shows boreholes, seismic profiles (red lines)

\section{Geological setting}

The TTZ is a major tectonic and geophysical lineament extending from the Baltic Sea in the northwest to the Black Sea in the southeast (e.g., Zielhuis and Nolet 1994; Pharaoh 1999); it defines a transition between the thick crust of the EEC and the thinner crust of the Palaeozoic Platform farther southwest (Fig. 1). The TTZ is about $50 \mathrm{~km}$ wide and it is and regional cross-sections (blue lines) that were used in this study. GF Grójec Fault, TTZ Teisseyre-Tornquist Zone

associated with a distinct perturbation of the Moho discontinuity. The depth to the Moho decreases from 42-49 km under the Polish part of the EEC to 31-38 km under the Palaeozoic Platform adjacent from the southwest (e.g., Guterch and Grad 2006; Guterch et al. 2010). The top of the Paleoproterozoic crystalline basement descends within the TTZ by at least $10 \mathrm{~km}$, sloping toward the SW (Mazur et al. 2015; Grad and Polkowski 2016; Krzywiec et al. 2017a). 
Fig. 3 Potential field maps of Poland. A coordinate system used in this and all subsequent figures is Poland 1992 that is based on the ETRS89 datum, GRS80 ellipsoid and the Transverse Mercator projection with $19^{\circ} \mathrm{E}$ as a central meridian. Seismic profiles and regional cross-sections used in the study are shown in red and blue with white outline, respectively. The edges of the Teisseyre-Tornquist Zone are depicted in black with white outline and main structural elements in white with black outline. a Bouguer anomaly map. b Magnetic anomaly reduced-to-pole (RTP). $G F$ Grójec Fault, HCF Holy Cross Fault, IZF Izbica-Zamość Fault, $K F$ Kock Fault, $U K F$ Urysnów-Kazimierz Fault
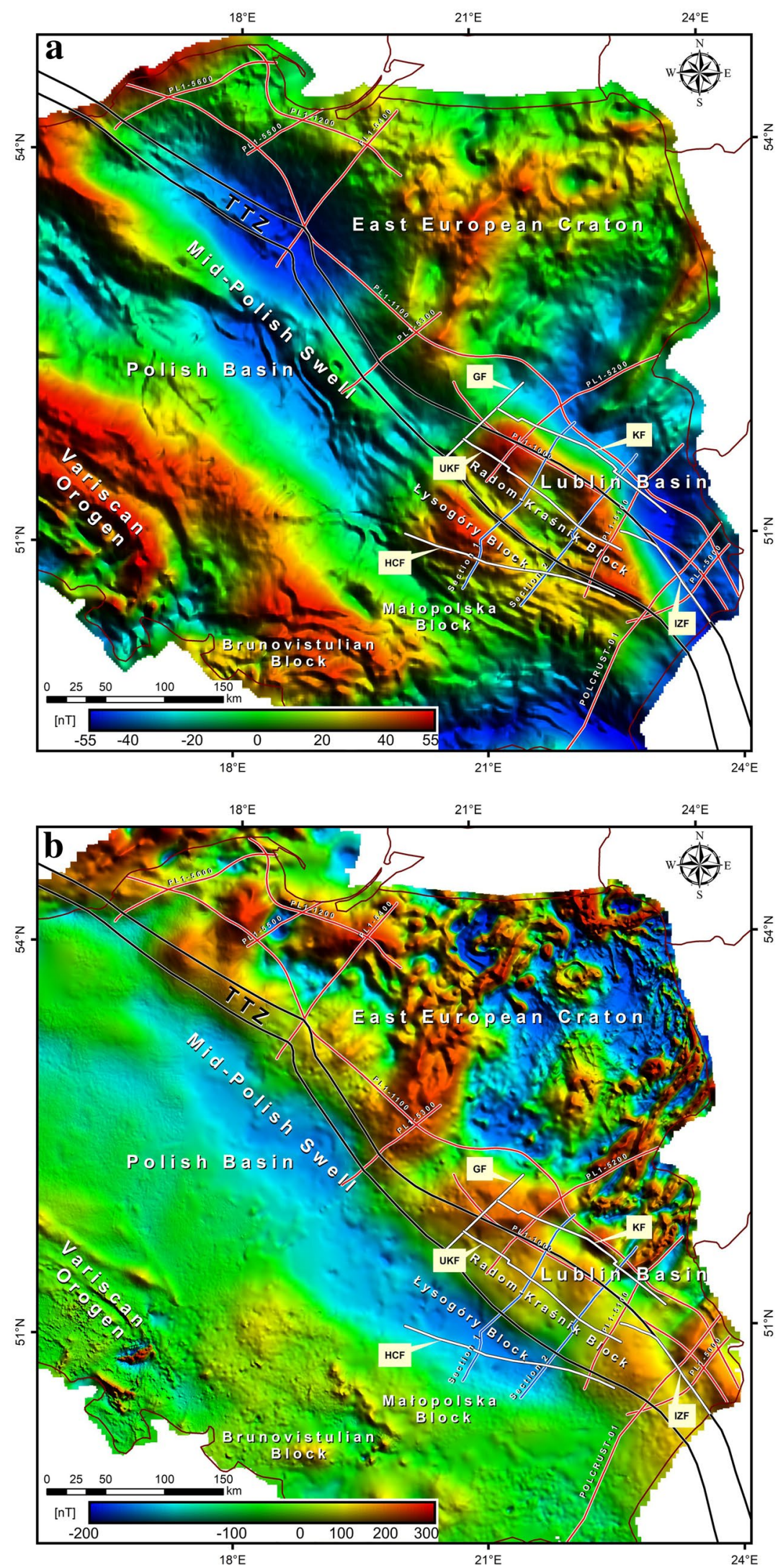
The distribution of S-wave velocities in the upper mantle obtained on the basis of seismic tomography proves that the TTZ coincides with a much wider mantle transition zone between the high-velocity S-wave domains underneath the EEC and the low-velocity domain beneath the Palaeozoic Platform (Zhu et al. 2015). The TTZ is also aligned with the direction of the faster $S$-wave propagation in the upper mantle (Zhu and Tromp 2013).

The TTZ is an obvious boundary in the gravity and magnetic anomaly maps (Królikowski and Petecki 1995; Królikowski and Wybraniec 1996; Wybraniec 1999; Bayer et al. 2002; Yegorova et al. 2007; Fig. 3), and also in the heat flow data indicating higher temperatures in the Palaeozoic Platform (Čermák et al. 1989; Majorowicz et al. 2003). Throughout its length, the TTZ is covered by thick Palaeozoic, Permian-Mesozoic and Cenozoic sedimentary basins. Therefore, the recognition of the contemporary structure and past tectonic evolution of the TTZ primarily relies on the interpretation of geophysical data that are in places complemented by borehole data.

The seismic structure of the EEC, revealed by refraction surveys, consists of three nearly horizontal and uniform layers with P-wave velocities of 6.1-6.4, 6.5-6.7, and $7.0-7.2 \mathrm{~km} / \mathrm{s}$, corresponding to the upper, middle and lower crust (Grad et al. 2002; Guterch and Grad 2006). The depth to the Moho increases from 39-45 km in NE Poland to $50 \mathrm{~km}$ beneath Lithuania (Guterch and Grad 2006). The crystalline basement of the EEC is composed of mediumto high-grade Paleoproterozoic metamorphic rocks: granulites, migmatites, and granite-gneisses that are intruded by Mesoproterozoic anorogenic plutons (Krzemińska et al. 2017). These rocks form NE-SW trending belts, truncated at a high angle by the TTZ (Bogdanova et al. 1996, 2008, 2015). The platform sedimentary cover in the Polish part of the EEC comprises three successions with Neoproterozoic (mostly Ediacaran)-Silurian, Devonian-Carboniferous, and Permian-Mesozoic ages. The most significant thickness and lateral extent have Ediacaran-lower Palaeozoic sediments. Their Cambrian-Ordovician section represents a passive continental margin succession. Upwards, it is succeeded by Silurian strata deposited in a foreland setting in front of the Caledonian orogen (Poprawa et al. 1999; Poprawa and Pacześna 2002; Poprawa 2006a). This early Palaeozoic basin is almost completely buried beneath younger sediments. Permian-Mesozoic, Carboniferous and Devonian strata overlie the top Silurian in Pomerania, central Poland and SE Poland, respectively. In each case, the top Silurian represents a clear erosional unconformity. The total thickness of Phanerozoic sediments increases south-westwards from $300 \mathrm{~m}$ on the Mazury-Belarus High to more than $10 \mathrm{~km}$ within the TTZ (Młynarski 1982; Grad and Polkowski 2016).

Deposition above the medium- to high-grade crystalline basement of the EEC in Poland commenced in the
Neoproterozoic during the rifting phases preceding the breakup of the Rodinia supercontinent (Poprawa 2006b). Neoproterozoic rift zones were either perpendicular (Orsha-Volyn Rift) or parallel (Tornquist Rift) to the EEC margin (Bogdanova et al. 2008). Rifting along the Orsha-Volyn axis was eventually abandoned, while ongoing extension along the Tornquist Rift led to the break-up of the Tornquist Ocean in the Ediacaran-earliest Cambrian (Poprawa and Pacześna 2002; Poprawa 2006b; Bogdanova et al. 2008). Neoproterozoic rifting in SE Poland is suggested by a characteristic syn-rift (Ediacaran) to thermal sagging (Cambrian-Ordovician) subsidence pattern (Poprawa and Pacześna 2002; Poprawa 2006b; Pacześna 2006, 2010, 2014). This scenario is consistent with facies development within the Ediacaran to Cambrian clastic basin fill (Pacześna 2006, 2014). The Ediacaran rifting is also confirmed by the extensive presence of Ediacaran rift-related magmatic rocks, mainly basalts (Bakun-Czubarow et al. 2002; Białowolska et al. 2002; Emetz et al. 2004; Krzemińska 2005). The Ediacaran age of this rifting event is constrained by radiometric dating of basaltic lavas and associated tuffs (Compston et al. 1995; Shumlyanskyy and Andréasson 2004; Elming et al. 2007; Shumlyanskyy et al. 2007).

The Palaeozoic Platform is characterised by thick upper crust with low P-wave velocities $(<6.2 \mathrm{~km} / \mathrm{s})$ down to $\sim 20 \mathrm{~km}$ and lower crust with velocity $6.5-7.2 \mathrm{~km} / \mathrm{s}$ (e.g., Grad et al. 2002; Guterch and Grad 2006). The depth to the Moho discontinuity decreases from 38 in central Poland to $31 \mathrm{~km}$ in northwestern Poland (Guterch and Grad 2006). The deepest known substratum of the Palaeozoic Platform consists of intensely deformed lower Palaeozoic sediments that were penetrated by boreholes in a narrow area of northern Poland along the TTZ. Their lithology is similar to that of the lower Palaeozoic succession filling the Caledonian foredeep farther NE (e.g., Modliński and Podhalańska 2010). The Carboniferous succession comprises laterally interfingered sediments of the Laurussian passive margin and Variscan foreland basin (e.g., Mazur et al. 2010). The foreland basin fill is variously deformed, whereas the passive margin sediments already belong to a platform cover. The latter also include a Permian-Mesozoic sedimentary fill of the Polish Basin reaching a maximum thickness of $\sim 8 \mathrm{~km}$. The largest thickness is attained within the Mid-Polish Trough, an elongated NW-SE depocentre adjacent to and SW of the TTZ (Dadlez et al. 1995). The trough was subsequently inverted into the Mid-Polish Swell during a Late Cretaceous to earliest Paleogene compressional event (e.g., Dadlez et al. 1995; Krzywiec 2002).

\section{Data and methods}

Gravity and magnetic data used in this study were obtained from the Central Geological Database (Central Geological Database 2017) managed by the Polish Geological Institute 
(http://baza.pgi.gov.pl/). The gravity database comprised measurements derived from 513,800 ground stations uniformly distributed over the study area. The gravity data were processed by a complete Bouguer correction using a digital terrain model and slab density of $2.67 \mathrm{~g} / \mathrm{cm}^{3}$. The gravity datum used was the international gravimetric standard IGSN71 (The International Gravity Standardization Net 1971) and theoretical gravity was based on the GRS80 (Geodetic Reference System '80) reference ellipsoid. The Bouguer gravity data were gridded at a $2000 \mathrm{~m}$ interval using a minimum curvature algorithm. The magnetic data base included 519,600 measurements of the Total Magnetic Intensity compiled from a number of ground surveys. These data were gridded at a $500 \mathrm{~m}$ interval using a minimum curvature algorithm and upward continued to $500 \mathrm{~m}$ mean terrain clearance.

The seismic data employed in this study were high-resolution seismic reflection lines of the PolandSPANTM survey (Krzywiec et al. 2014) obtained courtesy of ION Geophysical (Fig. 2). All currently published PolandSPAN ${ }^{\mathrm{TM}}$ seismic lines (Mazur et al. 2015, 2016a; Krzywiec et al. 2017a, b) are collated in Supplementary Material (ESM 1). The top Paleoproterozoic basement and top Ediacaran two-dimensional (2D) horizons interpreted from all ten PolandSPANTM profiles were used as input to gravity modelling. In addition, the top basement from the NE section (first $165 \mathrm{~km}$; Fig. 2) of the POLCRUST-01 public domain seismic reflection profile (Malinowski et al. 2013) was used (ESM 1). Finally, we also employed the top Paleoproterozoic basement and top Ediacaran horizons from two balanced geological crosssections through the Łysogóry Block and the northern part of the Małopolska Block (Fig. 2; Mazur et al. 2018; Gagała et al. 2018) that were partly based on industrial seismic surveys (ESM 1).

The collection of borehole data consists of well tops for the Ediacaran (597 wells) and crystalline Precambrian (239 wells). These data were derived from deep research boreholes and exploratory wells drilled by the Polish Geological Institute and the petroleum industry, respectively. Standardized formation tops were retrieved from the Central Geological Database operated by the Polish Geological Institute (Central Geological Database 2017). The overview of borehole data is provided in Electronic Supplementary Material (ESM 2). Forty-three research boreholes have density information available that is based on laboratory measurements of core samples (ESM 3).

Our approach to inversion of gravity data is based on the spatial method published by Barnes and Barraud (2012), which aims to build a geologically realistic model that is compatible with measured data and constraints. This method, originally developed for gravity gradient data (Barnes and Barraud 2012), can be also used for the gravity field; it deals with the non-uniqueness problem through a joint inversion of gravity data and depth information considered as an additional data set. The algorithm iteratively inverts for a surface, which represents the geometric interface between geologic bodies. The model bodies are defined by grids of rectangular prisms, each with assigned density and fixed top, that have their bottom depths adjusted by the algorithm to create the inverted surface. This approach is particularly useful when combining gravity data with depth horizons estimated from interpreted 2D seismic profiles to create a three-dimensional (3D) inversion for imaging subsurface geological bodies. The depth estimates (well tops, seismic 2D horizons) are treated as representing a set of measurements of the geological surface and are incorporated in the inversion together with the potential field data. The relative accuracy of different measurements is controlled by means of weighting (Barnes and Barraud 2012). For instance, the inversion can be forced to honour the depth measurements more closely than the potential field data by assigning to them larger weights in the matrix. This method appears appropriate when the depth measurements, such as well logs or high-resolution seismic profiles, are known to provide hard constraints in the inversion process-albeit with some associated uncertainty (Barnes and Barraud 2012).

One of the challenges in interpretation of gravity data is to separate the signals from shallow and deep geology. To separate the gravity effect related to the Moho boundary, which is clearly resolved within the TTZ by seismic data (e.g., Guterch et al. 2010), a simple two-layer forward model was built. The lower body, corresponding to the upper mantle (Fig. 4), extended from a flat base of the model arbitrary delimited at a depth of $55 \mathrm{~km}$ up to the Moho discontinuity. The latter was adopted from a grid integrating the results of all previous deep refraction soundings conducted in the territory of Poland (Majdański 2012). The upper body of the model represented Earth's crust. An additional complication was introduced by the presence of high-density upper mantle $\left(3.4 \mathrm{~g} / \mathrm{cm}^{3}\right)$ under the part of the Palaeozoic Platform (e.g., Janik et al. 2009) that is overlapped by the NW corner of the study area. In the seismic refraction models from this area, the high-velocity mantle is imaged as a layer below the Moho reaching down to a depth of 52-57 km (Janik et al. 2005, 2009). Therefore, a base of the forward model was chosen at a depth of $55 \mathrm{~km}$ to account for a maximum gravitational effect of the high-velocity/density mantle. A variable density contrast across the Moho was applied (Fig. 4) ranging from $0.45 \mathrm{~g} / \mathrm{cm}^{3}$ for the high-density mantle to $0.35 \mathrm{~g} / \mathrm{cm}^{3}$ for the normal mantle of the $\operatorname{EEC}\left(3.3 \mathrm{~g} / \mathrm{cm}^{3}\right)$. A density contrast of $0.35 \mathrm{~g} / \mathrm{cm}^{3}$ between the upper mantle and lower crust of the EEC was adopted from deep refraction surveys (e.g., Grad et al. 2002; Guterch and Grad 2006). The forward modelled gravity response of the mantle body was controlled by the magnitude of density contrast across the 


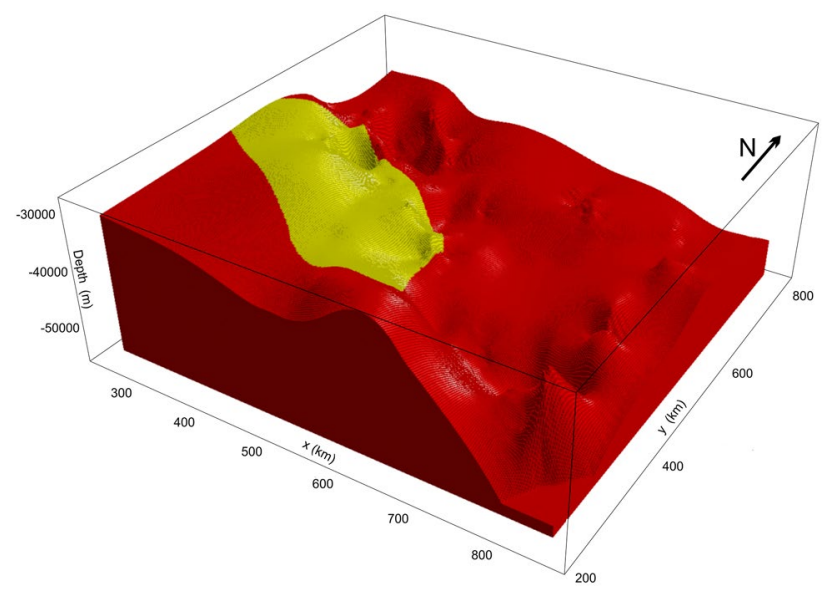

Fig. 4 Upper mantle body used to forward calculate a deeply sourced component of gravity signal. The top of the body corresponds to the Moho horizon compiled by Majdański (2012) based on data from 33 seismic refraction profiles. The flat base of the body was arbitrarily assumed at $55 \mathrm{~km}$ depth, i.e., below the deepest part of the Moho. A variable mantle density was applied for the calculation: (1) red colour represents the normal mantle with a density $3.3 \mathrm{~g} / \mathrm{cm}^{3}$ and a density contrast of $0.35 \mathrm{~g} / \mathrm{cm}^{3}$ across the Moho, and (2) yellow colour shows the high-density upper mantle with a density of $3.4 \mathrm{~g} / \mathrm{cm}^{3}$ and a density contrast of $0.45 \mathrm{~g} / \mathrm{cm}^{3}$ across the Moho. The extent of the highdensity mantle was adopted from Janik et al. (2009)

Moho and the geometry of the latter. The synthetic response of the lower body of our model, corresponding to the upper mantle, was then subtracted from the observed gravity signal. The remaining residual anomaly was considered to be produced by the crystalline crust and its sedimentary cover and it served as input data for the following inversion exercise.

The residual gravity data, after removing the effect of Moho depth variation, were inverted for the top of the Paleoproterozoic crystalline basement surface assuming a density contrast of $0.2 \mathrm{~g} / \mathrm{cm}^{3}$ across the top of basement-implying no lateral density variation in the basement or sediments. A body representing the Ediacaran-Phanerozoic sediments in a starting model was defined with the top at a depth of $110 \mathrm{~m}$ below sea level (minimum topographic elevation) and base at an arbitrary depth of $10 \mathrm{~km}$ corresponding to the expected average depth-to-basement within the SW slope of the EEC. The inversion procedure was performed iteratively until a satisfactory root-mean-square (RMS) deviation was achieved. For the top Ediacaran, the whole approach was replicated with different depth measurements (well tops and 2D seismic horizons) and assuming a lower density contrast of $0.1 \mathrm{~g} / \mathrm{cm}^{3}$ across the top of the Ediacaran. Altogether, three inverse models have been built for: (1) the top of the Paleoproterozoic in the whole study area (Fig. 2), (2) the top of the Ediacaran in the whole area, and (3) the top of the Ediacaran in SE Poland (yellow polygon in Fig. 2). This approach is justified by the use of control points for the top of the Paleoproterozoic and top of the Ediacaran that allow to get the correct depth values.

For needs of qualitative interpretation, the gravity and magnetic data were subjected to a series of transformations aimed at enhancing the features of the geophysical image generated by specific sources of gravity and magnetic anomalies and simultaneously filtering out the undesirable signals. The reduction-to-pole (RTP) transform was first applied to the magnetic anomaly data using magnetic inclination and declination values for 1989-representing the end of the 1980s, when the majority of data were acquired. Further filters and derivatives of the gravity and magnetic data were used to enhance specific signatures and to attenuate long wavelength signals related to deeper sources. To highlight discrete, regionally pervasive changes in crustal structure and density, the total horizontal derivative (THD) was applied to the Bouguer gravity and RTP magnetics. The THD showed distinct linear trends along the location of faults that juxtapose blocks of contrasting density or susceptibility (Grauch and Cordell 1987). The first vertical derivative sharpened up anomalies over their sources, allowing a clearer imaging of the causative structures (e.g., Blakely 1996). This enhancement also amplified short-wavelength anomalies of shallow sources. The $30 \mathrm{~km}$ low-pass filter removed wavelengths shorter than a specified cutoff and eliminated short-wavelength shallowsourced anomalies, isolating the effect of regional crystalline basement structure. The $160 \mathrm{~km}$ high-pass filters removed wavelengths longer than a specified cutoff and suppressed regional trends in the data, thus enhancing features related to shallower density or magnetisation contrasts.

A series of maps was produced based on the results of inverse modelling, including isobath maps for the Paleoproterozoic crystalline basement and the top Ediacaran as well as an isopach map for the Ediacaran. The results of qualitative interpretation were used for the adjustment of 3D geophysical grids to include geological features to the greatest extent possible.

\section{Qualitative analysis}

Interpreted structures, faults, thrusts and lineaments were presented using a uniform system of symbols and classified among two categories: (1) basement structures (pink lines), and (2) thin-skinned structures (white lines). These two sets of lineaments were separated based on filtered grids and taking into account that magnetic data mostly reveal faults rooted in the Paleoproterozoic basement. The results of interpretation are shown on the background of gravity and magnetic data as well as their selected derivatives (Figs. 5, 6; Supplementary Material ESM 4). The interpretation of 
potential field maps was additionally verified against seismic profiles of the PolandSPANTM survey.

Structural elements within and SW of the TTZ are dominated by a NW-SE structural grain (Fig. 5). Despite their various ages, these structures follow the strike of the TTZ, a structural trend presumably related to the presence of a basement ramp corresponding to the SW slope of the EEC (Mazur et al. 2015, 2016b; Krzywiec et al. 2017a, b). The NW-SE-oriented array of structures within the TTZ and adjacent part of the Palaeozoic Platform comprise two main types of structures: (1) normal to high-angle reverse faults formed or reactivated during the Late Cretaceous-Paleocene Alpine inversion of the Polish Basin (e.g., Dadlez et al. 1995; Krzywiec 2002), and (2) low-angle thrusts developed in the course of late Carboniferous Variscan shortening (Krzywiec et al. 2017a, b). The extent of the latter group of structures is limited to the SE part of the study area (Fig. 6) that corresponds to the Radom-Kraśnik and Łysogóry Blocks and the NE margin of the Małopolska Block (Fig. 3). These areas were described as a thin-skinned Variscan fold-and-thrust belt (Krzywiec et al. 2017a, b). The polarity of thrusts was inferred based on a rule that a local gravity high corresponds to the hanging wall of a thrust fault (Fig. 6; ESM 4). A new observation is that thrust tectonics are not limited to the Radom-Kraśnik Block as earlier reported (Krzywiec et al. 2017a, b) but also extend SW to the adjacent Łysogóry Block and NE Małopolska Block. The structural elements belonging to the inversion-related set of structures extend along the full length of the TTZ but are most pronounced in the central and NW parts of the study area, where Mesozoic rocks are widespread. Major faults delineate there at the core of the Mid-Polish Swell, a major anticline shaped by the Alpine inversion. However, many NW-SE faults were only reactivated during inversion and date back to the time when the Mid-Polish Trough was developed through a number of subsidence pulses in the Permian and early Mesozoic (e.g., Krzywiec 2009). Kinematics of faults, a bulk relative displacement in the case of multiple reactivation, were estimated assuming that a hanging wall of normal faults corresponds to a gravity low (Fig. 5; ESM 4). The exact position of structural elements was estimated using the THD map of the study area (Fig. 5b), since THD anomalies usually delineate positions of faults.

The RTP magnetic data and their derivatives show a very smooth pattern within and SW of the TTZ (Fig. 6; ESM 4). Since susceptibility of sediments is negligible, the lack of localised anomalies suggests a smooth top of the Paleoproterozoic crystalline basement without structuration imposed by basement-rooted faults. This outcome confirms earlier observations, based on seismic data, regarding the thinskinned character of Variscan thrusting within the SE part of the study area (Radom-Kraśnik Block; Krzywiec et al. 2017a, b). Furthermore, the magnetic data also imply a thin-skinned character of the Alpine inversion that apparently did not involve magnetic basement within the study area.

In contrast, basement faults are a common feature within the EEC that extends NE of the TTZ (Fig. 6; ESM 4). These faults are manifested by localised anomalies, especially within the THD map (Fig. 6b). There are three groups of basement faults: (1) NW-SE oriented, parallel to the TTZ, (2) N-S to NNW-SSE oriented, and (3) NE-SW oriented (Fig. 7; ESM 4). The first group of basement faults, trending NW-SE, is only present in the SW part of the study area, the Kock Fault Zone being the best known of them (Krzywiec et al. 2017a; Tomaszczyk and Jarosiński 2017). These are normal dip-slip faults with a hanging wall on the SW. Their location and kinematics well correlate with 2D seismic sections (Krzywiec et al. 2017a, b; Tomaszczyk and Jarosiński 2017). The geometry and kinematics of the NW-SE-oriented basement faults along with the seismic data by Krzywiec et al. (2017a) suggest that they were formed in an extensional regime before the end of early Palaeozoic. The remaining two sets of faults display apparently compatible kinematics, with a right-lateral strike-slip component along a $\mathrm{N}-\mathrm{S}$ direction and a left-lateral component along a NE-SW direction (Fig. 6; ESM 4). This relationship may suggest that they represent a conjugate set of faults. However, this purely kinematic inference is not necessarily true since NE-SW faults correlate with a deep Ediacaran graben recently recognised by seismic data (Krzywiec et al. 2018). Furthermore, the NE-SW-oriented faults apparently do not displace the TTZ (Fig. 6; ESM 4). In contrast, the N-S to NNW-SSE faults are seen to have an impact on the alignment of the TTZ.

An additional complication of the structural pattern is revealed by magnetic data in the NW part of the study area (Pomerania, offshore Poland) with an extra E-W structural trend, but this problem lies beyond the scope of this study. Many strong magnetic anomalies within the interior of the EEC are not necessarily related to fault structures. In this area of shallow Paleoproterozoic basement, the magnetic anomaly pattern is heavily influenced by lateral lithological changes with several Proterozoic intrusions (e.g., Krzemińska et al. 2017) as well as magnetite mineralisation (Kubicki 1984).

\section{Depth-to-basement results}

A 3D inverse gravity modelling exercise was set to define the top of the Paleoproterozoic crystalline basement and top of the Ediacaran. The residual gravity grid (see "Data and methods") and depth-to-basement estimates (well tops and $2 \mathrm{D}$ seismic horizons) were used as input measurements. The joint inversion of the gravity data and depth measurements 
Fig.5 Qualitative interpretation of gravity data. Structural elements overlaid on a the

Bouguer gravity, and $\mathbf{b}$ the total horizontal derivative of the Bouguer gravity
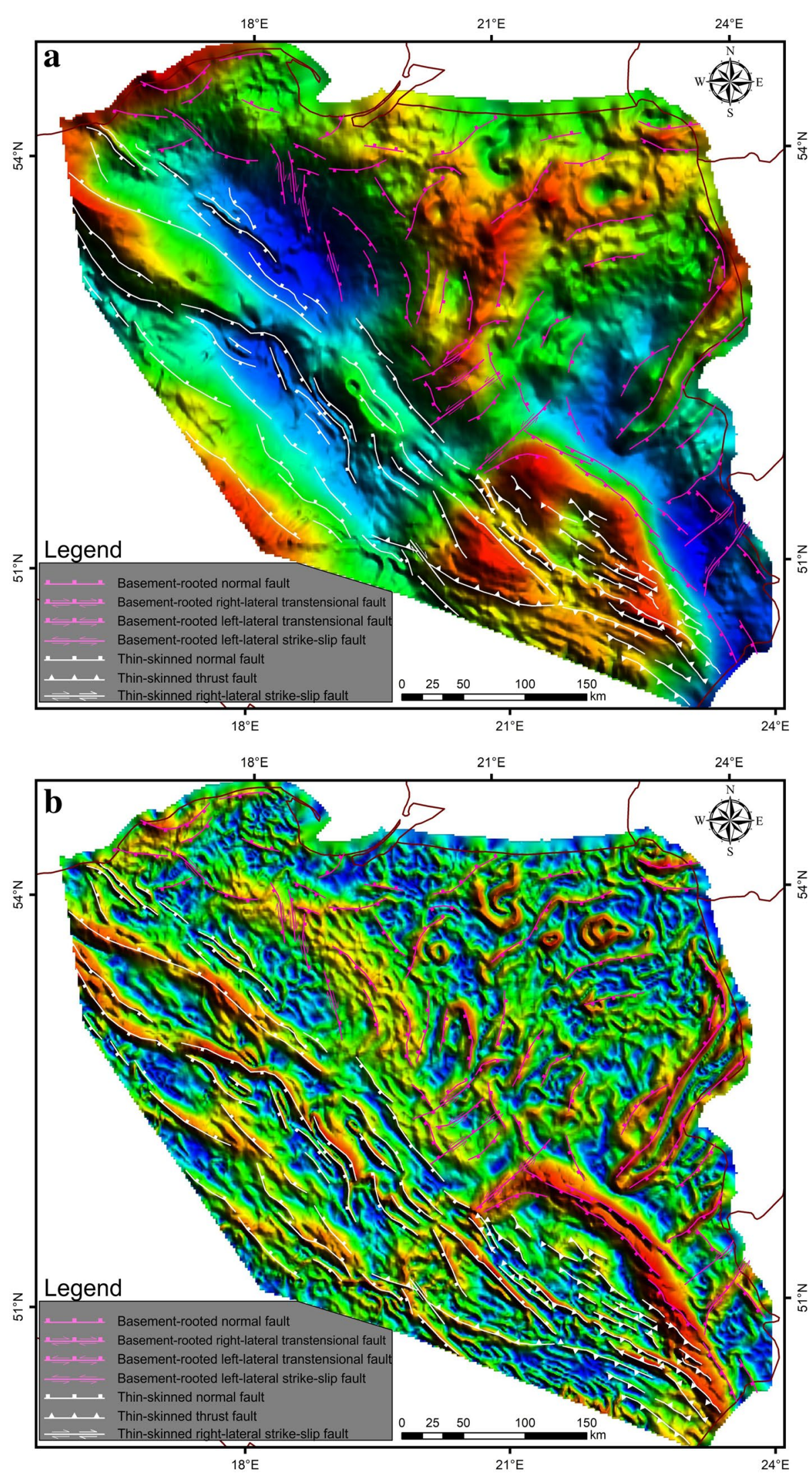
Fig.6 Qualitative interpretation of magnetic data. Structural elements overlaid on a reduced-topole (RTP) magnetic data, and b the total horizontal derivative of the RTP magnetic data
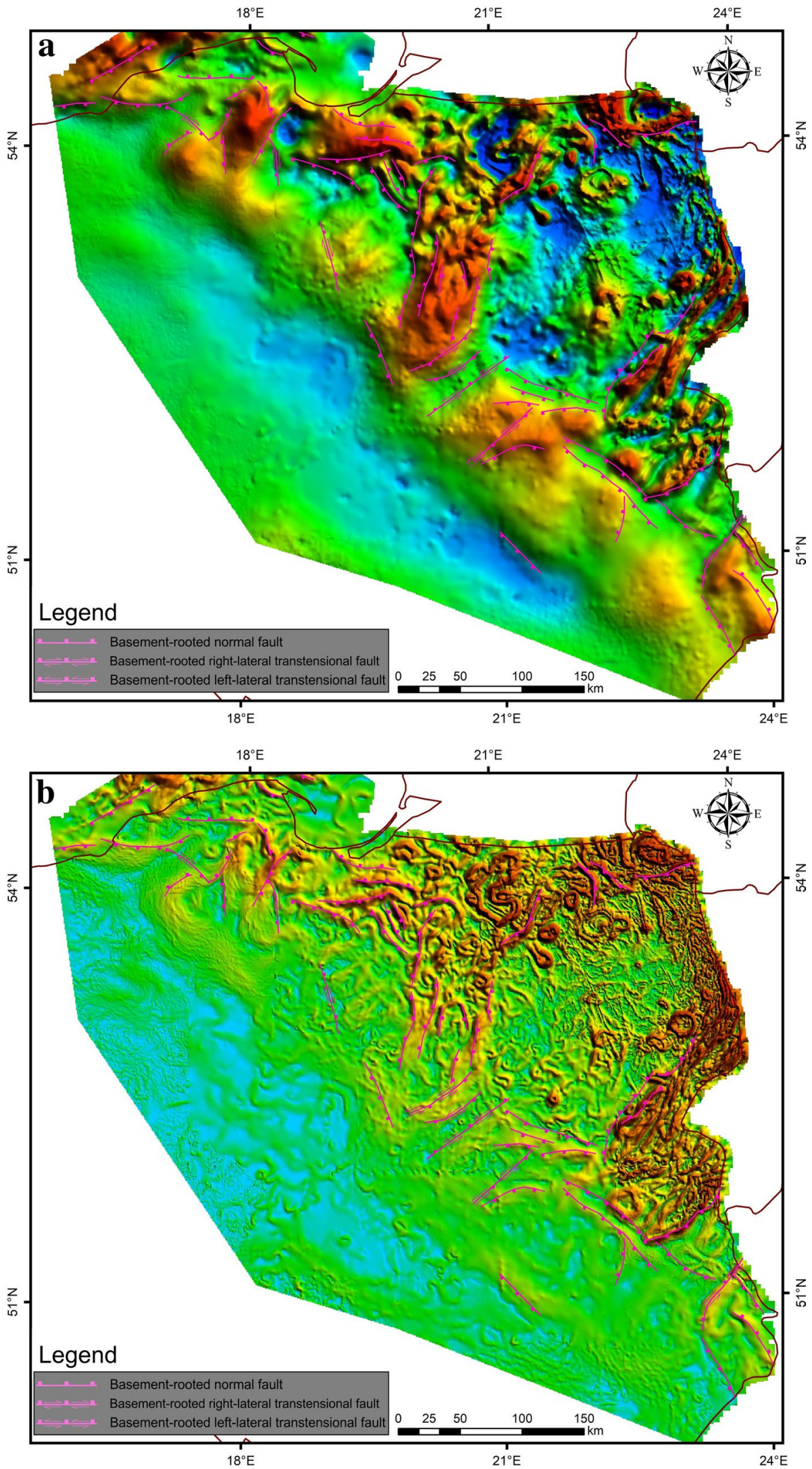


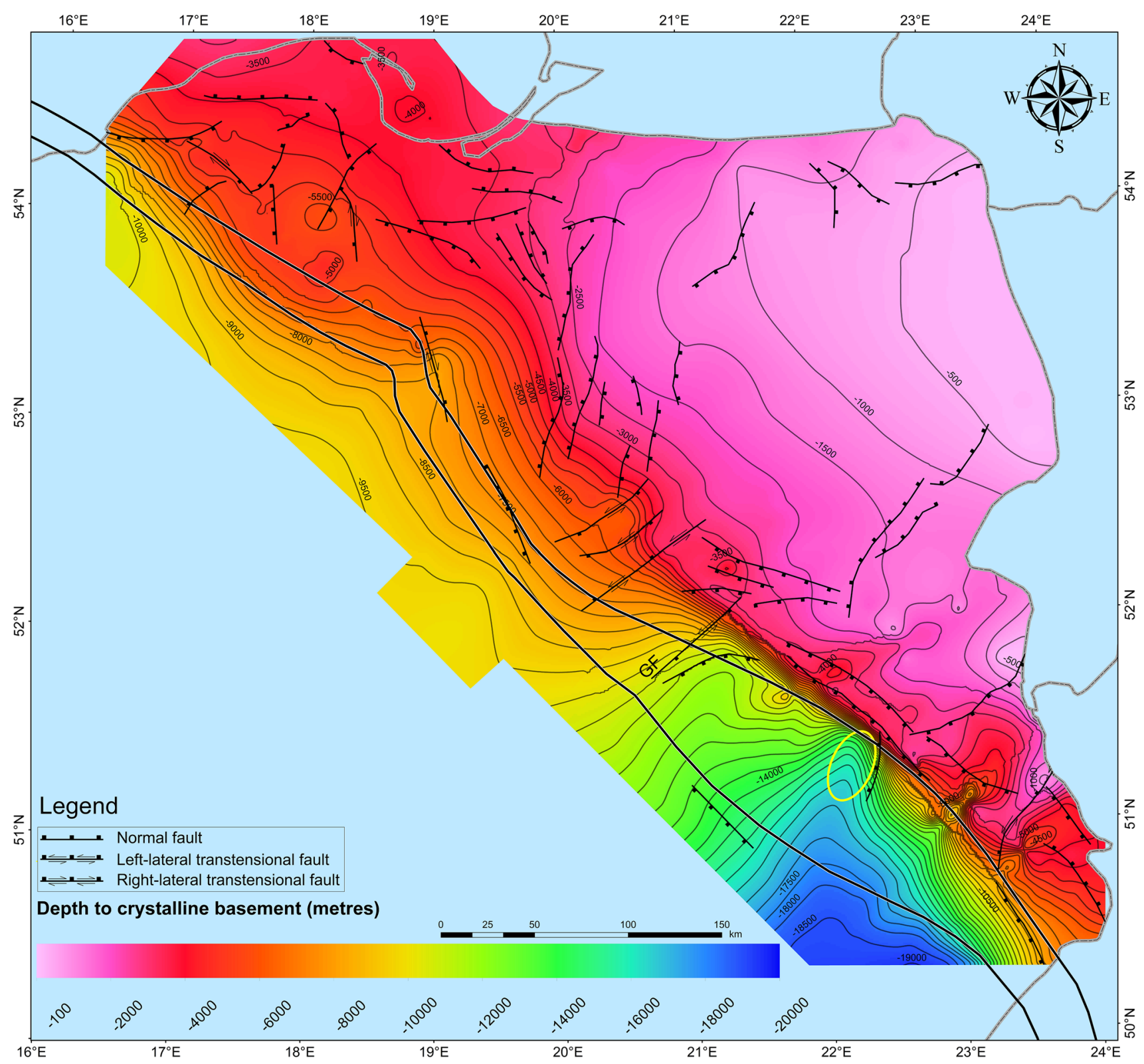

Fig. 7 Depth to Paleoproterozoic crystalline basement together with interpreted basement-rooted structural elements and isobath contour lines. The Teisseyre-Tornquist Zone is depicted in black with white outline. Yellow ellipse shows a Neoproterozoic graben (Krzywiec et al. 2018). GF Grójec Fault

the previous depth inversions, since it was missing reliable data on the depth to the Paleoproterozoic basement. The Ediacaran thickness grid was prepared only for the area covered by both the depth-to-Paleoproterozoic crystalline basement and depth-to-Ediacaran grids (Fig. 10).

The basement isobath map shows the smooth geometry of the top of the EEC Paleoproterozoic basement uniformly sloping toward the SW beneath the adjacent Palaeozoic Platform (Fig. 7). This is consistent with evidence provided by the RTP magnetic data and their derivatives (Fig. 6; ESM 4). The depth to the Paleoproterozoic 


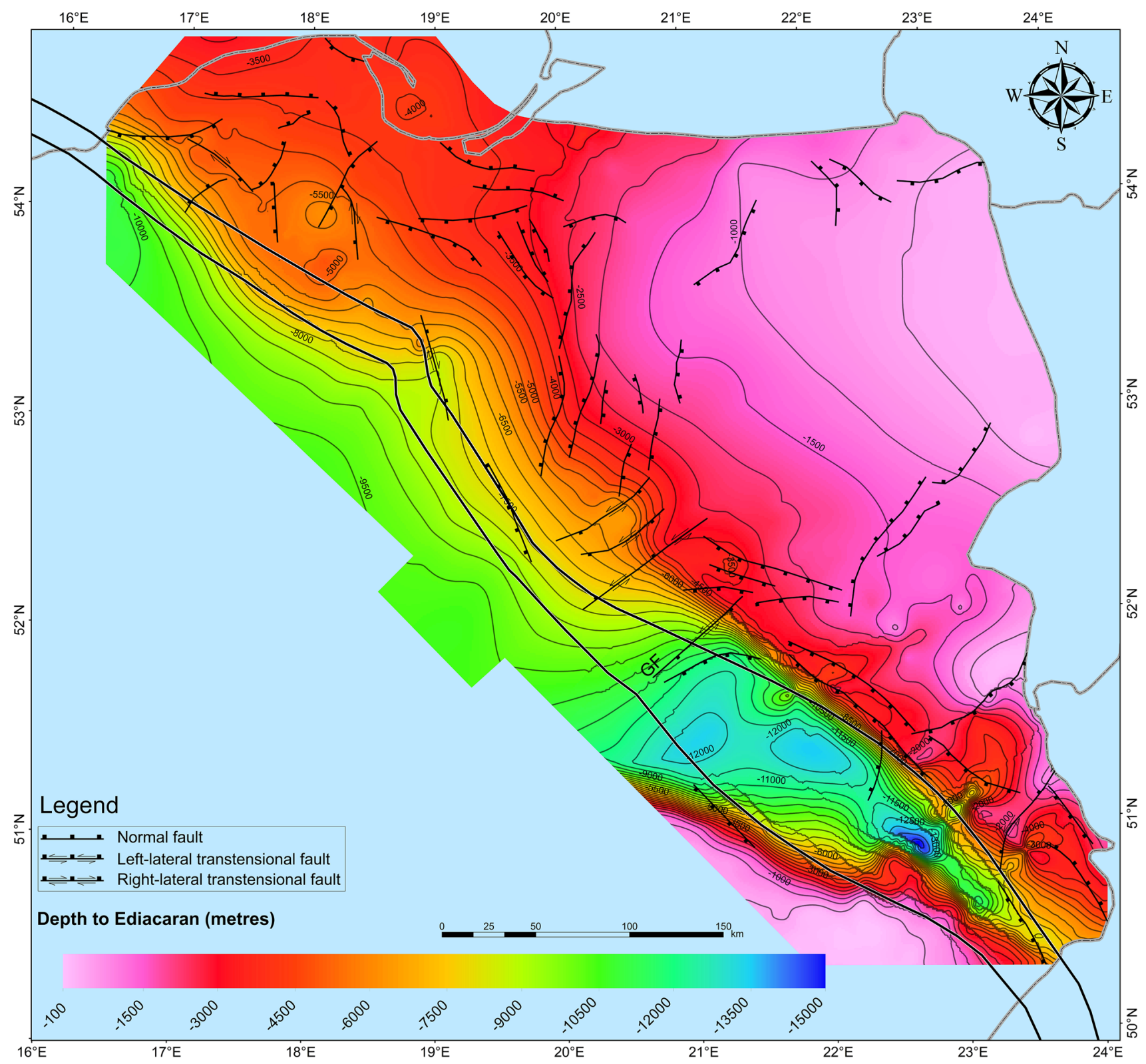

Fig. 8 Depth to the top of the Ediacaran together with interpreted basement-rooted structural elements and isobath contour lines. The TeisseyreTornquist Zone is depicted in black with white outline. GF Grójec Fault

basement increases from NE to SW by $\sim 11-16 \mathrm{~km}$, from $\sim 2$ to $13-18 \mathrm{~km}$, respectively (Fig. 7). This basement slope largely coincides with the position of the TTZ (Fig. 7). The basement is deeper on average by $6 \mathrm{~km}$ in the SW part of the study area $(16-18 \mathrm{~km}), \mathrm{SE}$ of the line representing the SW-ward projection of the Grójec Fault (Fig. 7). The NE edge of this basement low, corresponding to the area of the Łysogóry and Małopolska Blocks (Figs. 3, 7), continues into a NNE-SSW elongated depression (yellow ellipse in Fig. 7). The latter feature coincides with the Neoproterozoic graben imaged in one of the PolandSPAN ${ }^{\mathrm{TM}}$ seismic profiles and interpreted as an Ediacaran syn-rift structure (Krzywiec et al. 2018). The orientation of this Ediacaran graben approximately matches the trend of NE-SW basement faults having a left-lateral strike-slip component (Figs. 5, 6).

The horizon labelled as the top Ediacaran corresponds either to the top of Neoproterozoic sediments or the top of the Paleoproterozoic crystalline basement if the Neoproterozoic is missing. The most conspicuous feature of the top Ediacaran is its great depth within the Radom-Kraśnik Block and the western part of the Lublin Basin (Figs. 3, 8). Farther SW, the top of the Ediacaran rises to a shallow depth in the SW part of the Łysogóry Block and even 


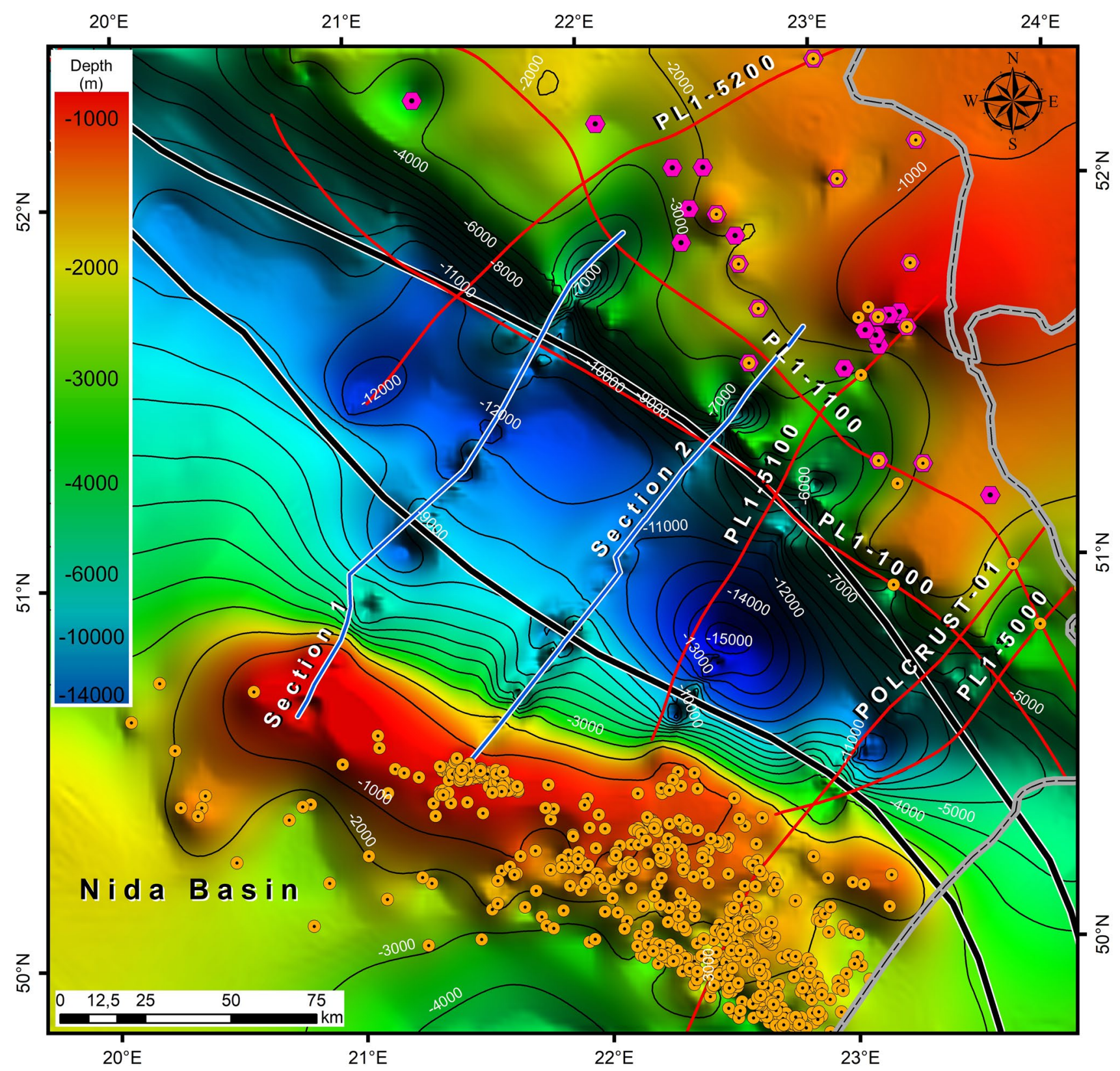

Fig. 9 The top of the Ediacaran isobath map for SE Poland derived from 3D joint inversion of gravity, seismic and well data. Orange circles and pink hexagons show boreholes that reached the Ediacaran and crystalline Paleoproterozoic, respectively. Seismic profiles (red lines, see ESM 1) and regional cross-sections (blue with white border lines, see ESM 1) used in the study are also depicted. Black lines

with white outline indicate the Teisseyre-Tornquist Zone. Bull-eye artefacts result from local incompatibilities of geological constraints (borehole vs. seismic data), but these do not affect the regional pattern. The root-mean-square (RMS) deviation describing the fit of the model is $3.8 \mathrm{mGal}$

shallower in the Małopolska Block (Fig. 9). In the latter, it is concealed only beneath thin Miocene strata (Buła et al. 2008). This structural high, following an axis of the MidPolish Swell (Figs. 3, 9), is clearly asymmetric with a big depression located on its NE side and the relatively shallow SW slope plunging beneath the Nida Basin (Fig. 9). Such a geometry might be related to the NE polarity of the Variscan fold-and-thrust belt that has been recognised in the area corresponding to a structural low in the top of the Ediacaran horizon (Fig. 9; Krzywiec et al. 2017a, b). The elevation of the top of the Ediacaran (Fig. 9) presently corresponds to a former axis of the Mid-Polish Trough, inverted in the MidPolish Swell (Fig. 2), suggesting a post-Variscan rearrangement of the top of the Ediacaran.

The isopach map (Fig. 10) shows that the vast part of sediments above the top of the Paleoproterozoic crystalline 


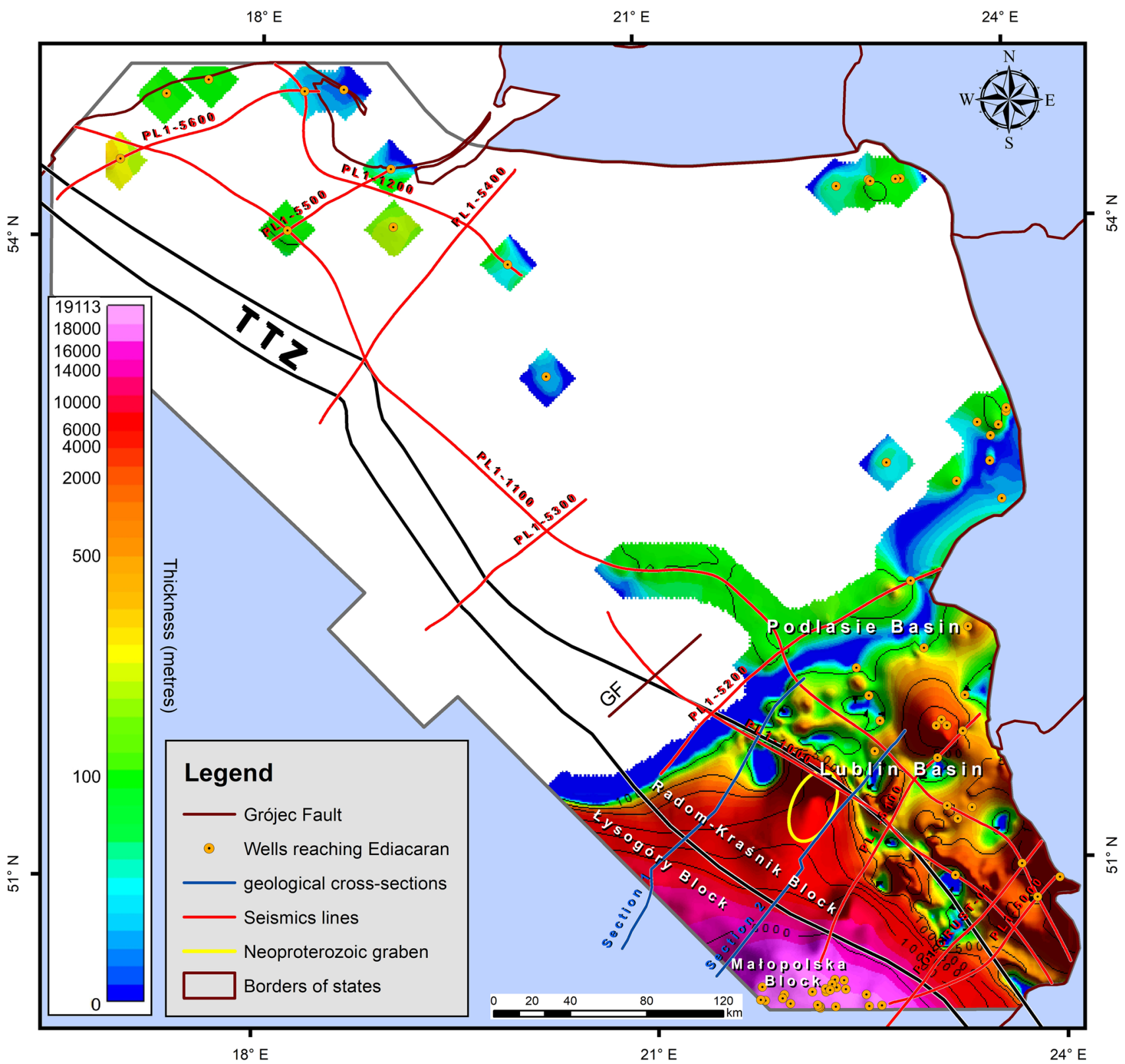

Fig. 10 Ediacaran thickness (isopach) map. Orange circles show boreholes that reached the Ediacaran. Seismic profiles (red with white outlines, see ESM 1) and balanced cross-sections (blue with white outlines, see ESM 1) used in the study are also shown. The Teisseyre-

basement is represented by a Neoproterozoic, presumably Ediacaran succession in the SE part of the TTZ and the adjacent Łysogóry and Małopolska Blocks. The Neoproterozoic isopachs delineate the NNE-SSW-oriented graben (a yellow ellipse in Fig. 10) that is also visualised in the Paleoproterozoic crystalline basement isobath map (Fig. 7). The thickest pile of Neoproterozoic sedimentary rocks extends NW-SE in the area of the Radom-Kraśnik, Łysogóry and the northern Małopolska Blocks, where it
Tornquist Zone (TTZ) is depicted in black with white outline. Yellow ellipse shows a Neoproterozoic graben (Krzywiec et al. 2018). GF Grójec Fault

extends almost from the surface to the top of the Paleoproterozoic crystalline basement at a depth of $16-18 \mathrm{~km}$. Of course, such a massive present-day thickness does not necessarily correspond to a primary sedimentary thickness, but the original thickness could have been tectonically increased (Gagała 2005). Judging from the borehole data, the majority of Neoproterozoic rocks corresponds to an Ediacaran anchimetamorphic flysch succession (Buła et al. 2008). These rocks were found in about 1000 boreholes 
Fig. 11 Comparison of present results for the Paleoproterozoic crystalline basement with the previous depth-to-basement studies based on seismic data. a The difference between the present results and the seismic basement by Grad and Polkowski (2016) that was derived from a three-dimensional P-wave velocity model. b The difference between the present results and the top of crystalline basement grid by Majdański (2012) that was based on 33 seismic refraction profiles. In both cases, reddish and bluish colours indicate areas where seismic basement is higher and lower than the present result, respectively. Seismic profiles are shown in red with white outline. Black lines with white outline show TeisseyreTornquist Zone (TTZ). Pink hexagons show boreholes that reached the Paleoproterozoic crystalline basement
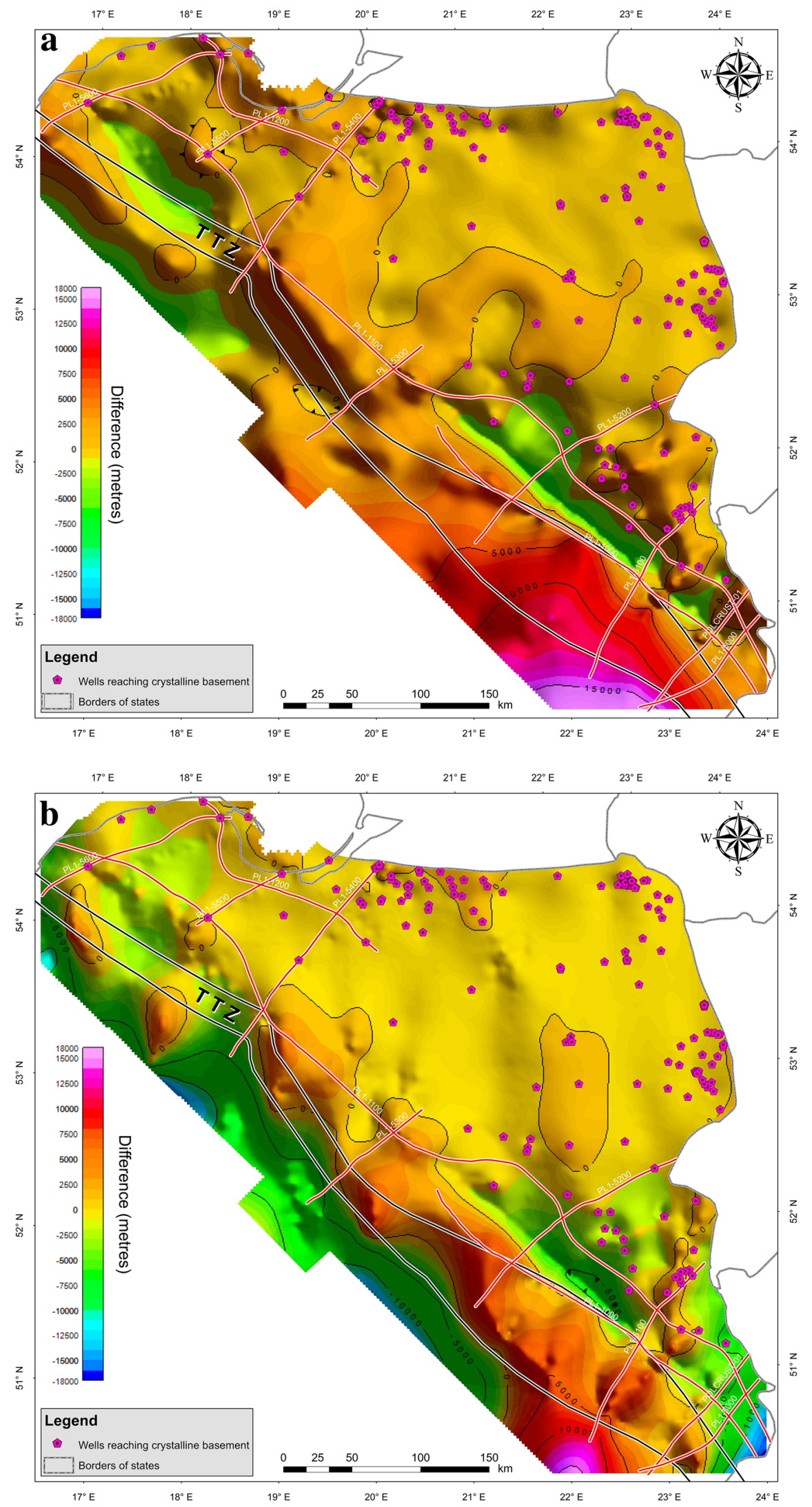

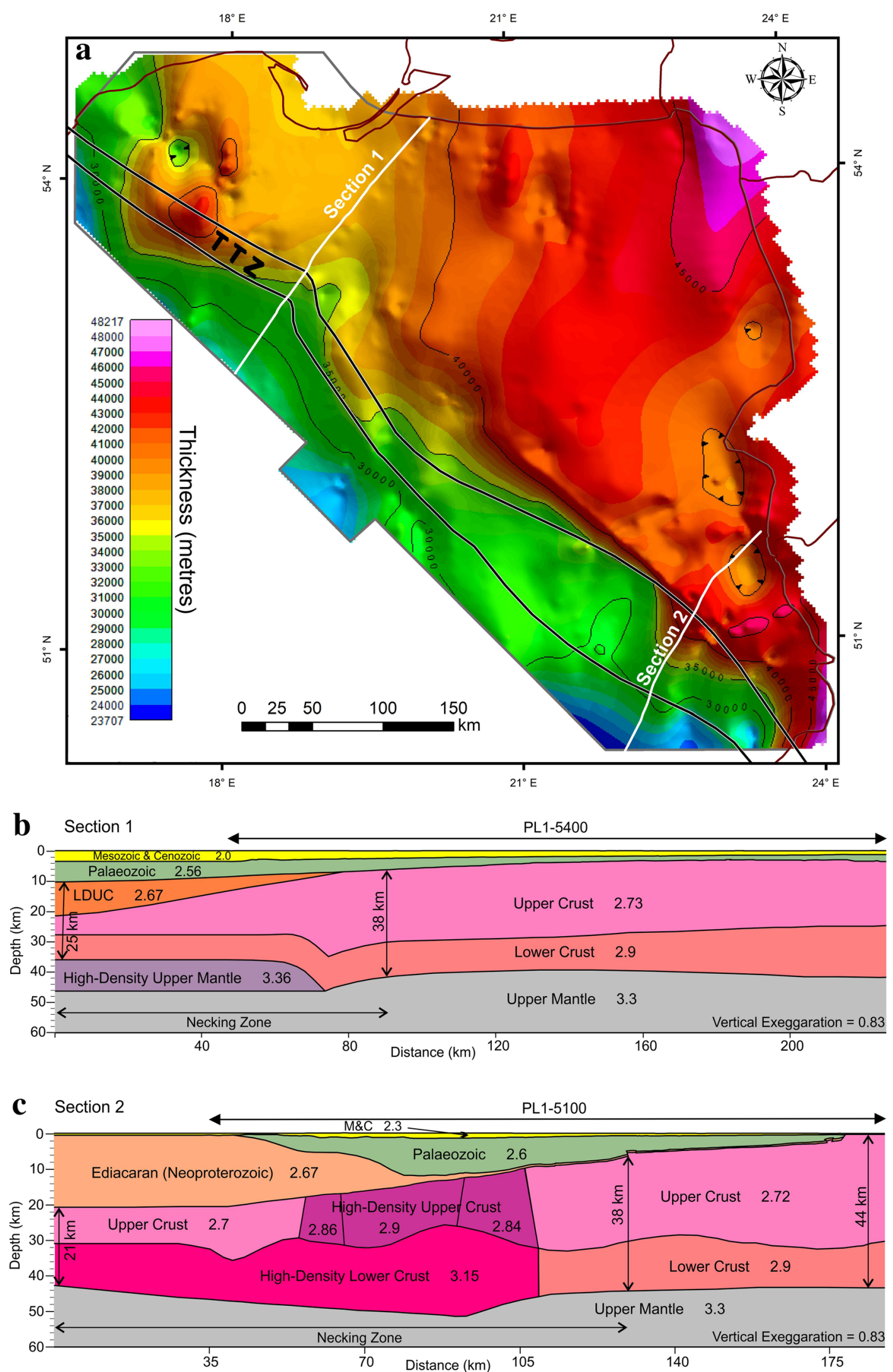
4Fig. 12 Crustal architecture across the Teisseyre-Tornquist Zone (TTZ) and NE Poland. a Crystalline crust thickness map with isopach lines; white lines show the location of two sections through the model; black lines with white outlines indicate the extent of the TTZ. b Section 1 across NW Poland. c Section 2 across SE Poland (see text for details). The top of the Paleoproterozoic basement and top of the Ediacaran horizons are the outcome of our modelling exercise. The Moho discontinuity is from Majdański (2012). LDUC low-density upper crust, $M \& C$ Mesozoic and Cenozoic

located in SE Poland, concealed under younger sediments of various Ordovician to Miocene ages (Buła et al. 2008). However, it is possible that older non-metamorphic to weakly metamorphic Neoproterozoic rocks are hidden at a greater depth, especially in the area of the Łysogóry and Małopolska Blocks beyond the reach of wells.

The extent of Neoproterozoic (Ediacaran) sediments over the EEC is mostly limited to the area of SE Poland, where they occur mainly in the Lublin and Podlasie Basins SE of the Grójec Fault (Fig. 10). In this area, the Ediacaran succession reaches a thickness of 2000-2500 m. A narrow strip of sediments with a vastly reduced thickness stretches out NW of the Grójec Fault (Fig. 10). Thin Ediacaran successions have been also reported from central and NE Poland in the revised chronostratigraphic logs of archive boreholes (Central Geological Database 2017).

\section{Discussion and conclusions}

Our study used higher resolution potential field data than previous 3D gravity modelling studies (Yegorova et al. 2007; Maystrenko and Scheck-Wenderoth 2013) and was focused on the area constrained by new seismic reflection surveys. Our first goal was to compare our results with the depth-to-basement studies entirely based on compilation of seismic refraction data and borehole information (Majdański 2012; Grad and Polkowski 2016). The compilation by Majdański (2012) was based on the results of 33 deep seismic refraction profiles. The top of the Paleoproterozoic crystalline basement horizon was interpreted in this study as corresponding to seismic P-wave velocities of $6.0-6.1 \mathrm{~km} / \mathrm{s}$. The top of seismic basement by Grad and Polkowski (2016) was derived from a three-dimensional velocity model built upon the results of deep refraction soundings. In this case, a seismic velocity typical of the top of basement was assumed at $\sim 5.75 \mathrm{~km} / \mathrm{s}$ without specifying the character of basement rocks (crystalline vs. consolidated). To compare the present results to the seismicderived basement models by Majdański (2012) and Grad and Polkowski (2016), we subtracted their grids from the top of the Paleoproterozoic crystalline basement calculated in this study (Fig. 11). All three basement models are fairly similar in the interior of the EEC, where the sedimentary cover is relatively thin and the depth-to-basement is controlled by wells. The dissimilarities appear in the vicinity of the TTZ and farther SW beyond this zone. The difference between the grids (Fig. 11) suggests that outside of well control, the seismic basement by Grad and Polkowski (2016) is shallower than the Paleoproterozoic crystalline basement and must correspond to the top of the Ediacaran or even the top of lower Palaeozoic (Fig. 11a). This is most clearly visible in SE Poland and the area of the Pomeranian Caledonides in the NW, where the seismic basement by Grad and Polkowski (2016) is close to the position of the Caledonian unconformity (Mazur et al. 2016a). Consequently, the grid by Grad and Polkowski (2016) most likely represents the pre-Variscan substratum of the Palaeozoic Platform in these areas. The crystalline basement by Majdański (2012) is shallower than the basement from our gravity inversion in a narrow zone following the TTZ and within the northern Małopolska Block (Fig. 11b). Farther SW, the crystalline basement by Majdański (2012) is deeper than the present result and it likely corresponds to the top of the middle crust, i.e., it is located below the low-velocity upper crystalline crust of the Palaeozoic Platform.

The present study shows that the Małopolska and Łysogóry Blocks, having the upper crust built mainly of Neoproterozoic (Ediacaran) series, are located adjacent to that part of the EEC, where the Ediacaran is also present and attains a considerable thickness (Fig. 10). This casts a shadow on the terrane concepts postulated for the Małopolska and Łysogóry Blocks (e.g., Dadlez et al. 2005; Nawrocki et al. 2007; Narkiewicz et al. 2011, 2015; Walczak and Belka 2017), as it implies that the Neoproterozoicfloored terranes must have coincidently docked directly in front of this part of the EEC, where a thick Neoproterozoic succession is also present. Furthermore, the smooth and uniformly sloping top of the Paleoproterozoic basement (Fig. 7) is difficult to reconcile with the presence of a suture zone with strike-slip kinematics along the TTZ (e.g., Dadlez et al. 2005; Narkiewicz et al. 2015). This corollary is consistent with the lack of basement-rooted faults within the TTZ as revealed by the results of qualitative analysis (Fig. 6).

The Paleoproterozoic basement slope within the TTZ, as it is mapped in the present paper (Fig. 7), coincides with a perturbation in a depth to Moho (e.g., Guterch and Grad 2006; Mazur et al. 2015). The Moho gets shallower SW of the TTZ by $\sim 6 \mathrm{~km}$ (Grad et al. 2002; Guterch and Grad 2006). A cumulative effect of the basement slope and elevation of the Moho is thinning of the Precambrian crystalline crust by $15-17 \mathrm{~km}$ to $20-25 \mathrm{~km}$ beneath the Palaeozoic Platform (Fig. 12). This result is consistent with the outcomes of the 3D lithosphere-scale density model of the Central European Basin System by Maystrenko and Scheck-Wenderoth (2013). Consequently, the TTZ appears 
to be a crustal necking zone matching the definition proposed by Osmundsen and Ebbing (2008), Péron-Pinvidic and Manatschal (2009) and Mohn et al. (2012). A further implication is the ductile nature of crustal thinning caused by a major extensional event probably related to the breakup of Rodinia (Fig. 12). The Ediacaran age of crustal thinning is constrained by a massive $\mathrm{SW}$-ward increase of the Ediacaran thickness in SE Poland (Fig. 10). In Central and NW Poland, there is little Ediacaran documented within the reach of wells (Fig. 10) but the low-velocity upper crust deeply buried beneath the Palaeozoic Platform (Fig. 12b; Grad et al. 2002; Guterch and Grad 2006) was interpreted as a low-grade metamorphic volcano-sedimentary sequence (Puziewicz 2006) and may correspond to a Neoprotrozoic succession (Mazur et al. 2016b). If this is a case, crustal thinning in NW Poland would be even more extreme than predicted by the present study.

While the concept of Ediacaran separation of Baltica from Rodinia is well-established (Torsvik et al. 1992, 1996; Poprawa and Pacześna 2002; Cocks and Torsvik 2005; Poprawa 2006b), the depth to the Paleoproterozoic crystalline basement and the Ediacaran thickness maps (Figs. 7, 10) provide an additional argument in favour of roughly simultaneous rifting in NE-SW and NW-SE directions, the latter ultimately leading to the opening of the Tornquist Ocean. The presence of the NE-SW-oriented Ediacaran graben identified in SE Poland (Figs. 7, 10) is additionally corroborated by a PolandSPANTM seismic section (Krzywiec et al. 2018). The orientation of this half-graben is similar to the strike of basement-rooted faults that were revealed by qualitative analysis (Figs. 5,6) and the direction of the Orsha-Volyn Rift developed in the Neoproterozoic within the Rodinia supercontinent (e.g., Bogdanova et al. 1996, 2008; Fig. 1).

In conclusion, the results presented are consistent with a model where important features of crustal architecture along the TTZ were shaped by the Ediacaran extensional tectonics related to fragmentation of Rodinia. Subsequent deformations were of mostly thin-skinned character as revealed by qualitative analysis and the Paleoproterozoic crystalline basement configuration. A dominant NW-SE orientation of structural grain was to a large extent controlled by the presence of a crustal neck corresponding to the TTZ. However, within the interior of the EEC, the pre-Neoproterozoic NE-SW structural trend is present that was later reactivated, e.g., by the Orsha-Volyn Rift and associated structural elements.

Acknowledgements ION Geophysical is thanked for consent to use PolandSPANTM seismic data. M. Mikołajczak and S. Mazur acknowledge financial support from the Polish National Science Centre Grant no. UMO-2011/01/B/ST10/04713. Gravity and magnetic data used in our study can be obtained from the Central Geological Database (CGDB) managed by the Polish Geological Institute (http://baza.pgi. gov.pl/). The authors thank Karel Schulmann for editorial handling of the paper. Constructive comments from Alexandra Guy and two Anonymous Reviewers helped to improve our work. The authors are indebted to Chris Green from the University of Leeds for his helpful comments on the manuscript, and correction of the English of the text.

Open Access This article is distributed under the terms of the Creative Commons Attribution 4.0 International License (http://creativeco mmons.org/licenses/by/4.0/), which permits unrestricted use, distribution, and reproduction in any medium, provided you give appropriate credit to the original author(s) and the source, provide a link to the Creative Commons license, and indicate if changes were made.

\section{References}

Bakun-Czubarow N, Białowolska A, Fedoryshyn Y (2002) Neoproterozoic flood basalts of Zabolottya and Babino Beds of the volcanogenic Volhynian Series and Polesie Series dolerites in the western margin of the East European Craton. Acta Geol Pol 52(4):481-496

Barnes G, Barraud J (2012) Imaging geologic surfaces by inverting gravity gradient data with depth horizons. Geophysics 77(1):G1G11. https://doi.org/10.1190/geo2011-0149.1

Bayer U, Grad M, Pharaoh TC, Thybo H, Guterch A, Banka D, Lamarche J, Lassen A, Lewerenz B, Scheck M, Marotta A-M (2002) The southern margin of the East European Craton: new results from seismic sounding and potential fields between the North Sea and Poland. Tectonophysics 360:301-314. https://doi. org/10.1016/S0040-1951(02)00359-1

Białowolska A, Bakun-Czubarow N, Fedoryshyn Y (2002) Neoproterozoic flood basalts of the upper beds of the Volhynian Series (East European Craton). Geol Q 46(1):37-58

Blakely RJ (1996) Potential theory in gravity and magnetic applications. Cambridge University Press, New York, $441 \mathrm{pp}$

Bogdanova S, Paskevich IK, Gorbatschev R, Oryluk MI (1996) Riphean rifting and major Palaeoproterozoic crustal boundaries in the basement of the East European Craton: geology and geophysics. Tectonophysics 268:1-21. https://doi.org/10.1016/S0040 -1951(96)00232-6

Bogdanova SV, Bingen B, Gorbatschev R, Kheraskova TN, Kozlov VI, Puchkov VN, Volozh YA (2008) The East European Craton (Baltica) before and during the assembly of Rodinia. Precambrian Res 160(1):23-45. https://doi.org/10.1016/j.precamres.2007.04.024

Bogdanova S, Gorbatschev R, Skridlaite G, Soesoo A, Taran L, Kurlovich D (2015) Trans-Baltic Palaeoproterozoic correlations towards the reconstruction of supercontinent Columbia/Nuna. Precambrian Res 259:5-33. https://doi.org/10.1016/j.preca mres.2014.11.023

Buła Z, Żaba J, Habryn R (2008) Tectonic subdivision of Poland: southern Poland (Upper Silesian Block and Małopolska Block). Przegląd Geologiczny 56(10):912-920

Central Geological Database (2017) Polish Geological Institute. http:// baza.pgi.gov.pl/. Accessed 17 Nov 2017

Čermák V, Šafanda J, Guterch A (1989) Deep temperature distribution along three profiles crossing the Teisseyre-Tornquist tectonic zone in Poland. Tectonophysics 164(2-4):151-163. https://doi. org/10.1016/0040-1951(89)90009-7

Cocks LRM, Torsvik TH (2005) Baltica from the late Precambrian to mid-Palaeozoic times: the gain and loss of a terrane's identity. Earth Sci Rev 72:39-66. https://doi.org/10.1016/j.earsc irev.2005.04.001 
Compston W, Sambridge MS, Reinfrank RF, Moczydlowska M, Vidal G, Claesson S (1995) Numerical ages of volcanic rocks and the earliest faunal zone within the Late Precambrian of east Poland. J Geol Soc Lond 152:599-611. https://doi.org/10.1144/gsjgs .152.4.0599

Dadlez R, Narkiewicz M, Stephenson RA, Visser MTM, Van Wees JD (1995) Tectonic evolution of the Mid-Polish Trough: modelling implications and significance for central European geology. Tectonophysics 252(1):179-195. https://doi.org/10.1016/00401951(95)00104-2

Dadlez R, Marek S, Pokorski J (2000) Geological map of Poland without Cenozoic deposits scale 1:1000000. Polish Geological Institute, Warszawa

Dadlez R, Grad M, Guterch A (2005) Crustal structure below the Polish Basin: is it composed of proximal terranes derived from Baltica? Tectonophysics 411(1-4):111-128. https://doi.org/10.1016/j.tecto .2005.09.004

Elming S, Kravchenko SN, Layer P, Rusakov OM, Glevasskaya AM, Mikhailova NP, Bachtads EV (2007) Palaeomagnetism and 40Ar/39Ar age determinations of the Ediacaran traps from the southwestern margin of the East European Craton Ukraine: relevance to the Rodinia break-up. J Geol Soc Lond 164:969-982. https://doi.org/10.1144/0016-76492005-163

Emetz A, Piestrzyński A, Zagnitko V (2004) Geological framework of the Volhyn copper fields with a review of the Volhyn flood basalt province (western margin of the East-European Craton). Ann Soc Geol Pol 74:257-265

Gagała $€$ (2005) Pre-Ordovician polyphase tectonics of the Cambrian sequences in the Kielce Unit, Holy Cross Mts. (Central Poland). Geol Q 49(1):53-66

Gągała Ł, Mazur S, Krzywiec P, Salwa S, Jarosiński M (2018) Shortening partitioning across the Variscan orogen in SE Poland. 16th Meeting of the Central European Tectonic Studies Group, Rytro, 18-21 April 2018. Geol Geophys Environ 44(1):157-158

Grad M, Polkowski M (2016) Seismic basement in Poland. Int J Earth Sci 105(4):1199-1214. https://doi.org/10.1007/s0053 1-015-1233-8

Grad M, Guterch A, Mazur S (2002) Seismic refraction evidence for crustal structure in the central part of the Trans-European Suture Zone in Poland. In: Winchester JA, Pharaoh TC, Verniers J (eds) Palaeozoic amalgamation of Central Europe. Geological Society of London, Special Publication, vol 201, pp 295-309. https://doi. org/10.1144/GSL.SP.2002.201.01.14

Grad M, Polkowski M, Ostaficzuk SR (2016) High-resolution 3D seismic model of the crustal and uppermost mantle structure in Poland. Tectonophysics 666:188-210. https://doi.org/10.1016/j. tecto.2015.10.022

Grauch V, Cordell L (1987) Limitations of determining density or magnetic boundaries from the horizontal gradient of gravity or pseudogravity data. Geophysics 52:118-121. https://doi. org/10.1190/1.1442236

Guterch A, Grad M (2006) Lithospheric structure of the TESZ in Poland based on modern seismic experiments. Geol Q 50:23-32

Guterch A, Wybraniec S, Grad M, Chadwick R, Krawczyk C, Ziegler P, De Vos W, Thybo H (2010) Crustal structure and structural framework. In: Doornenbal J, Stevenson A (eds) Petroleum Geological Atlas of the Southern Permian Basin Area. EAGE Publications, Houten, pp 11-23

Janik T, Grad M, Guterch A, Dadlez R, Yliniemi J, Tiira T, Keller GR, Gaczyński E, CELEBRATION 2000 Working Group (2005) Lithospheric structure of the Trans-European Suture Zone along the TTZ-CEL03 seismic transect (from NW to SE Poland). Tectonophysics 411(1-4):129-156. https://doi.org/10.1016/j.tecto .2005.09.005

Janik T, Grad M, Guterch A (2009) Seismic structure of the lithosphere between the East European Craton and the Carpathians from the net of CELEBRATION 2000 profiles in SE Poland. Geol Q 53(1):141-158

Królikowski C, Petecki Z (1995) Gravimetric Atlas of Poland. Państwowy Instytut Geologiczny, Warszawa

Królikowski C, Wybraniec S (1996) Gravity and magnetic maps of Poland-historical background and modern presentation. Publ Inst Geophys Polish Acad Sci M18(273):87-92

Krzemińska E (2005) The outline of geochemical features of the Late Neoproterozoic volcanic activity in the Lublin-Podlasie basin eastern Poland. Mineral Soc Pol Spec Papers 26:47-51

Krzemińska E, Krzemiński L, Petecki Z, Wiszniewska J, Salwa S, Żaba J, Gaidzik K, Williams IS, Rosowiecka O, Taran L, Johansson A, Pécskay Z, Demaiffe D, Grabowski J, Zieliński G (2017) Geological map of crystalline basement in the Polish part of the East European Platform 1:1 000 000. Państwowy Instytut Geologiczny, Warsaw

Krzywiec P (2002) Mid-Polish Trough inversion-Seismic examples main mechanisms and its relationship to the Alpine-Carpathian collision. In: Bertotti G, Schulmann K, Cloetingh S (eds) Continental collision and the tectonosedimentary evolution of forelands. European Geosciences Union Stephan Mueller Special Publication Series, vol 1, pp 151-165

Krzywiec P (2009) Devonian-Cretaceous repeated subsidence and uplift along the Teisseyre-Tornquist zone in SE Poland-insight from seismic data interpretation. Tectonophysics 475(1):142-159. https://doi.org/10.1016/j.tecto.2008.11.020

Krzywiec P, Malinowski M, Mazur S, Buffenmyer V, Lewandowski M (2014) Structure and Phanerozoic evolution of the SW edge of the East European Craton in Poland-new insight from high-effort seismic reflection data (project PolandSPAN). Geol Sudet 42:46-48

Krzywiec P, Mazur S, Gągała Ł, Kufrasa M, Lewandowski M, Malinowski M, Buffenmyer V (2017a) Late Carboniferous thinskinned compressional deformation above the SW edge of the East European craton as revealed by seismic reflection and potential field data-Correlations with the Variscides and the Appalachians. In: Law RD, Thigpen JR, Merschat AJ, Stowell HH (eds) Linkages and Feedbacks in Orogenic Systems. Geological Society of America Memoir, vol 213, pp 353-372

Krzywiec P, Gągała Ł, Mazur S, Słonka Ł, Kufrasa M, Malinowski M, Pietsch K, Golonka J (2017b) Variscan deformation along the Teisseyre-Tornquist Zone in SE Poland: thick-skinned structural inheritance or thin-skinned thrusting? Tectonophysics 718:83-91. https://doi.org/10.1016/j.tecto.2017.06.008

Krzywiec P, Poprawa P, Mikołajczak M, Mazur S, Malinowski M (2018) Deeply concealed half-graben at the SW margin of the East European Craton (SE Poland) - evidence for Neoproterozoic rifting prior to the break-up of Rodinia. J Palaeogeogr 7(1):88-97. https://doi.org/10.1016/j.jop.2017.11.003

Kubicki S (1984) Mineralization in the crystalline basement of NorthEastern Poland. Biuletyn Instytutu Geologicznego 347:49-54

Majdański M (2012) The structure of the crust in TESZ area by kriging interpolation. Acta Geophys 60:59-75

Majorowicz JA, Čermak V, Śafanda J, Krzywiec P, Wróblewska M, Guterch A, Grad M (2003) Heat flow models across the TransEuropean Suture Zone in the area of the POLONAISE'97 seismic experiment. Phys Chem Earth A/B/C 28(9):375-391

Malinowski M, Guterch A, Narkiewicz M, Probulski J, Maksym A, Majdański M, Środa P, Czuba W, Gaczyński E, Grad M, Janik T, Jankowski L, Adamczyk A (2013) Deep seismic reflection profile in Central Europe reveals complex pattern of Paleozoic and Alpine accretion at the East European Craton margin. Geophys Res Lett 40(15):3841-3846

Maystrenko YP, Scheck-Wenderoth M (2013) 3D lithosphere-scale density model of the Central European Basin System and adjacent areas. Tectonophysics 601:53-77 
Mazur S, Aleksandrowski P, Turniak K, Krzemiński L, Mastalerz K, Górecka-Nowak A, Kurowski L, Krzywiec P, Żelaźniewicz A, Fanning MC (2010) Uplift and late orogenic deformation of the Central European Variscan belt as revealed by sediment provenance and structural record in the Carboniferous foreland basin of western Poland. Int J Earth Sci 99(1):47-64. https://doi. org/10.1007/s00531-008-0367-3

Mazur S, Mikołajczak M, Krzywiec P, Malinowski M, Buffenmyer V, Lewandowski M (2015) Is the Teisseyre-Tornquist Zone an ancient plate boundary of Baltica? Tectonics 34(12):2465-2477. https://doi.org/10.1002/2015TC003934

Mazur S, Mikołajczak M, Krzywiec P, Malinowski M, Lewandowski M, Buffenmyer V (2016a) Pomeranian Caledonides NW Polanda collisional suture or thin-skinned fold-and-thrust belt? Tectonophysics 692:29-43. https://doi.org/10.1016/j.tecto.2016.06.017

Mazur S, Mikołajczak M, Krzywiec P, Malinowski M, Buffenmyer V, Lewandowski M (2016b) Reply to Comment by M Narkiewicz and Z Petecki on "Is the Teisseyre-Tornquist Zone an ancient plate boundary of Baltica?". Tectonics 35(6):1600-1607. https://doi. org/10.1002/2016TC004127

Mazur S, Gągała Ł, Kufrasa M, Krzywiec P (2018) Application of two-dimensional gravity models as input parameters to balanced cross-sections across the margin of the East European Craton in SE Poland. J Struct Geol 116:223-233. https://doi.org/10.1016/j. jsg.2018.05.013

Młynarski S (1982) The structure of deep basement in Poland in the light of refraction seismic surveys. Geol Q 26(2):285-296

Modliński Z, Podhalańska T (2010) Outline of the lithology and depositional features of the lower Paleozoic strata in the Polish part of the Baltic region. Geol Q 54(2):109-121

Mohn G, Manatschal G, Beltrando M, Masini E, Kusznir N (2012) Necking of continental crust in magma poor rifted margins: evidence from the fossil Alpine Tethys margins. Tectonics 31:TC1012. https://doi.org/10.1029/2011TC002961

Narkiewicz M, Grad M, Guterch A, Janik T (2011) Crustal seismic velocity structure of southern Poland: preserved memory of a preDevonian terrane accretion at the East European Platform margin. Geol Mag 148(2):191-210

Narkiewicz M, Maksym A, Malinowski M, Grad M, Guterch A, Petecki Z, Probulski J, Janik T, Majdański M, Środa P, Czuba W (2015) Transcurrent nature of the Teisseyre-Tornquist Zone in Central Europe: results of the POLCRUST-01 deep reflection seismic profile. Int J Earth Sci 104(3):775-796

Nawrocki J, Dunlap J, Pecskay Z, Krzemiński L, Żylińska A, Fanning M, Kozłowski W, Salwa S, Szczepanik Z, Trela W (2007) Late Neoproterozoic to Early Palaeozoic palaoegeography of the Holy Cross Mountains (Central Europe): an integrated approach. J Geol Soc 164(2):405-423

Osmundsen PT, Ebbing J (2008) Styles of extension offshore midNorway and implications for mechanisms of crustal thinning at passive margins. Tectonics 27:TC6016. https://doi. org/10.1029/2007TC002242

Pacześna J (2006) Evolution of late Neoproterozoic rift depocentres and facies in the Lublin-Podlasie sedimentary basin. Prace Państowego Instytutu Geologicznego 186:9-37 (in Polish with English summary)

Pacześna J (2010) The evolution of late Ediacaran riverine-estuarine system in the Lublin-Podlasie slope of the East European Craton southeastern Poland. Polish Geol Inst Spec Papers 27:1-96

Pacześna J (2014) Lithostratigraphy of the Ediacaran deposits in the Lublin-Podlasie sedimentary basin (eastern and south-eastern Poland). Biuletyn Państwowego Instytutu Geologicznego 460:124 (in Polish with English summary)

Péron-Pinvidic G, Manatschal G (2009) The final rifting evolution at deep magma-poor passive margins from Iberia-Newfoundland: a new point of view. Int J Earth Sci 98:1581-1597. https://doi. org/10.1007/s00531-008-0337-9

Pharaoh TC (1999) Palaeozoic terranes and their lithospheric boundaries within the Trans-European Suture Zone (TESZ): a review. Tectonophysics 314:17-41. https://doi.org/10.1016/S0040 -1951(99)00235-8

Poprawa P (2006a) Development of the Caledonian collision zone along the western margin of Baltica and its relation to the foreland basin. Prace Państwowego Instytutu Geologicznego 186:189-214 (in Polish with English summary)

Poprawa P (2006b) Neoproterozoic break-up of the supercontinent Rodinia/Pannotia recorded by development of sedimentary basins at the western slope of Baltica. Prace Państowego Instytutu Geologicznego 186:165-188 (in Polish with English summary)

Poprawa P, Pacześna J (2002) Late Neoproterozoic to Early Palaeozoic development of a rift at the Lublin-Podlasie slope of the East European Craton-analysis of subsidence and facies record (eastern Poland). Przegląd Geologiczny 50(1):49-63 (in Polish with English summary)

Poprawa P, Sliaupa S, Stephenson R, Lazauskiene J (1999) Late Vendian-Early Palaeozoic tectonic evolution of the Baltic Basin: regional implications from subsidence analysis. Tectonophysics 314:219-239. https://doi.org/10.1016/S0040-1951(99)00245-0

Puziewicz J (2006) Lower crust and uppermost mantle rocks in the area of the POLONAISE'97 seismic experiment petrologic-seismic models. Prace Państowego Instytutu Geologicznego 188:53-68 (in Polish with English summary)

Shumlyanskyy L, Andréasson PG (2004) New geochemical and geochronological data from the Volyn Flood Basalt in Ukraine and correlation with large igneous events in Baltoscandia. In: 26th Nordic geological winter meeting GFF, vol 126, pp 85-86

Shumlyanskyy L, Andréasson PG, Buchan KL, Ernst RE (2007) The Volynian Flood Basalt Province and Coeval (Ediacaran) Magmatsm in Baltoscandia and Laurentia. Mineral J 29(4):47-53

Smit J, van Wees JD, Cloetingh S (2016) The Thor suture zone: from subduction to intraplate basin setting. Geology 44(9):707-710. https://doi.org/10.1130/G37958.1

Tomaszczyk M, Jarosiński M (2017) The Kock Fault Zone as an indicator of tectonic stress regime changes at the margin of the East European Craton (Poland). Geol Q 61(4):908-925

Torsvik TH, Smethurst MA, Van der Voo R, Trench A, Abrahamsen N, Halvorsen E (1992) Baltica A synopsis of Vendian-Permian palaeomagnetic data and their palaeotectonic implications. Earth Sci Rev 33(2):133-152. https://doi.org/10.1016/0012-8252(92)90023 $-\mathrm{M}$

Torsvik TH, Smethurst MA, Meert JG, Van der Voo R, McKerrow WS, Brasier MD, Sturt BA, Walderhaug HJ (1996) Continental breakup and collision in the Neoproterozoic and Palaeozoic - a tale of Baltica and Laurentia. Earth Sci Rev 40(3-4):229-258

Walczak A, Belka Z (2017) Fingerprinting Gondwana versus Baltica provenance: $\mathrm{Nd}$ and $\mathrm{Sr}$ isotopes in Lower Paleozoic clastic rocks of the Małopolska and Łysogóry terranes southern Poland. Gondwana Res 45:138-151. https://doi.org/10.1016/j.gr.2017.02.002

Winchester JA, The Pace TMR Network Team (2002) Palaeozoic amalgamation of Central Europe: new results from recent geological and geophysical investigations. Tectonophysics 360(1-4):5-21. https://doi.org/10.1016/S0040-1951(02)00344-X

Wybraniec S (1999) Transformations and visualization of potential field data. Polish Geol Inst Spec Papers 1:1-59

Yegorova T, Bayer U, Thybo H, Maystrenko Y, Scheck-Wenderoth M, Lyngsie SB (2007) Gravity signals from the lithosphere in the Central European Basin System. Tectonophysics 429(1-2):133163. https://doi.org/10.1016/j.tecto.2006.10.002

Zhu H, Tromp J (2013) Mapping tectonic deformation in the crust and upper mantle beneath Europe and the North Atlantic Ocean. 
Science 341(6148):871-875. https://doi.org/10.1126/scien ce. 1241335

Zhu H, Bozdağ E, Tromp J (2015) Seismic structure of the European upper mantle based on adjoint tomography. Geophys J Int 201(1):18-52. https://doi.org/10.1093/gji/ggu492
Zielhuis A, Nolet G (1994) Deep seismic expression of an ancient plate boundary in Europe. Science 265:79-81. https://doi.org/10.1126/ science.265.5168.79 